$70-19,341$

MCCAULEY, III, Roy Barnard, 1943-

EARLY EFFECTS OF PHENOBARBITAL ON CYTOPLASMIC

RNA IN RAT LIVER.

The Ohio State University, Ph.D., 1970

Pharmacology

University Microfilms, A XEROX Company , Ann Arbor, Michigan 
EARLY EFFECTS OF PHENOBARBITAL ON CYTOPLASMIC

RNA IN RAT LIVER

\section{DISSERTATION}

Presented in Partial Fulfillment of the Requirements for the Degree Doctor of Philosophy in the Graduate

School of The Ohio State University

by

Roy Barnard McCauley, III, B.S.

$* * * * *$

The Ohio State University

1970

Approved by:

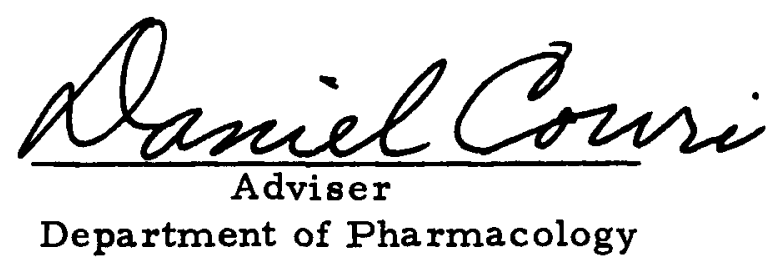




\section{ACKNOW LEDGMENTS}

I would like to particularly thank Dr. Daniel Couri for the extensive time and effort that he has invested in my graduate education and especially in the study described in the following pages. Without Dr. Couri's council and patience over the last four years this study would not have been conceived or completed.

I would also like to thank Dr. B. H. Marks for his helpful suggestions throughout the course of these and related experiments.

Other students and members of the Department of Pharmacology who have provided assistance in these experiments and advice in their interpretation are Drs. John O. Lindower, Madeline M. Hall and Michael Pereira. Dr. N. Baba and Claire McDonald of the Department of Pathology, The Ohio State University deserve particular thanks for their kind assistance in some of the work described in this manuscript.

I would like to express my sincere appreciation to Daria Cverna for her assistance and patience in the preparation of this manuscript.

The support of the predoctoral fellowship GM 01417 from the National Institutes of Health is acknowledged. 


\section{VITA}

September 20, 1943

1965

1970

$1965-1970$
Born - Chicago, Illinois

B.S., The Ohio State University

Ph. D., The Ohio State University

NIH Trainee, Pharmacology Training Grant GM 01417.

\section{Publications and Presentations}

McCauley, R.B. and Couri, D. (Spon: B. H. Marks): Effect of Phenobarbital on Adenine Nucleotide Levels and ATP Turnover in Livers of Rats. The Pharmacologist 11 (2): 285, 1969.

McCauley, R. B. and Couri, D. (Spon: J. V. Danellis): Early Effect of Phenobarbital on Microsomal RNA. Fed. Proc. 1970.

$$
\text { Fields of Study }
$$

Major Field:

Autonomic Pharmacology, Drs. B. H. Marks and R. Dagir$c$ manjian

Biological Oxidations, Drs, G. Brierly, A. J. Merola and J. Riske

Drug Metabolism, Drs. D. Couri and A. J. Merola

Enzymology and Protein Biochemistry, Dr. J. Alben

Protein Synthesis and Cellular Control, Drs. F.A. Kruger and $\mathrm{R}$. McCluer 
Minor Field

Endocrinology, Drs. K. Brownell and K. Nishikawara

Neuroanatomy, , Drs. A. O. Humbertson and J. Hall

Neurochemistry, Dr. R. McCluer

Neuroendocrine Pharmacology, Dr. H. Goldman

Neuromuscular Physiology, Dr. E. Bozler 


\section{CONTENTS}

$\begin{array}{lr}\text { ACKNOWLEDGMENTS } & \text { ii } \\ \text { VITA } & \mathrm{iii} \\ \text { LIST OF TABLES } & \mathrm{vii} \\ \text { LIST OF ILLUSTRATIONS } & \text { viii } \\ \text { DEFINITIONS AND ABBREVIATIONS } & \mathrm{ix} \\ \text { INTRODUCTION } & 1\end{array}$

$\begin{array}{ll}\text { METHODS } & 10\end{array}$

Treatment of Animals $\quad-10$

Estimation of ATP, ADP, AMP, DNA and ${ }^{32} \mathrm{Pi}$

Incorporation into ATP 11

Tissue Preparations $\quad 12$

Extraction of RNA 15

Binding of $\mathrm{Rb}_{1}$ to "Stripped" RER 16

Measurement of Incorporation of ${ }^{14} \mathrm{C}$ Leucine

Estimation of the Synthesis of Nuclear RNA 18

Estimation of the Half-Life of Microsomal RNA 19

Measurement of Radioactivity and Other Analytical $\begin{array}{ll}\text { Methods } & 19\end{array}$

$\begin{array}{ll}\text { Materials } & 20\end{array}$

RESULTS

Estimation of Adenine Nucleotide Levels and ATP Turnover in Rat Liver and its Relationship to the Adrenal Cortex

Appearance of RNA in the Microsomal Fraction of Rat Liver 
Influence of Phenobarbital on Hepatic Synthesis and Degradation of RNA

Effect of Phenobarbital Treatment on In Vitro

Binding of Polysomal RNA

The Effect of Cycloheximide and Phenobarbital on the Appearance of Ribosomes in the Cytoplasm

DISCUSSION 


\section{LIST OF TABLES}

Table

Page

1 The Effect of Phenobarbital on the Adenine

Nucleotide Content of Rat Liver

2 The Effect of Phenobarbital on ATP Turnover in Adrenalectomized Rats

3 Effect of Phenobarbital Treatment on Plasma Corticosterone

4 The Effect of Phenobarbital on the Appearance of Microsomal RNA in Adrenalectomized Rats

5 Effect of Phenobarbital on Specific Activity of RNA in Microsomal Subfractions

6 Effect of Phenobarbital on Specific Activity of RNA in Microsomal Subfractions

7 Incorporation of ${ }^{14} \mathrm{C}$ Leucine into Ribosome Bound Polypeptides

8 Effect of Phenobarbital Treatment on Binding of Polysomes to RER

9 The Influence of Cycloheximide Pretreatment on the Specific Activity of Cytoplasmic Ribosomes 


\section{LIST OF ILLUSTRATIONS}

Figure

Page

1 The Effect of Pretreatment with Phenobarbital on the In Vitro Demethylation of Aminopyrine

4,5

2 The Effect of Phenobarbital Treatment on Liver Weight and Microsomal Protein

3 Preparation of Tissue Fractions

4 The Effect of Phenobarbital on ATP Turnover

5 Microsomal RNA in Phenobarbital Treated Rats 31,32

6 Early Influence of Phenobarbital on RNA Synthesis 41, 42

7 Effect of Phenobarbital on the Degradation of Microsomal RNA

8 Rat Liver Polysomal Profile

9 "Stripped" RER

10 Reconstituted RER from Saline Treated Rats

11 Reconstituted RER from Phenobarbital Treated Rats 55, 56

12 Proposed Relationship of Protein Synthesis to Appearance of Cytoplasmic Ribosomes 
ATP, ADP, AMP

DNA

DOC

$\operatorname{DPN}(\mathrm{H})$

ER

PCA

${ }^{32} \mathrm{Pi}$

$R b_{1}, R b_{2}, R b_{3}, R b_{4}$

ribosomal RNA

ribos omes

RER

$\mathbf{S}$

SER

$\mathrm{TPN}(\mathrm{H})$ adenosine triphosphate, adenosine diphosphate, adenosine monophosphate

deoxyribonucleic acid

sodium desoxycholate

oxidized ( reduced) diphosphopyridine nucleotide

hepatic endoplasmic reticulum

perchloric acid

${ }^{32} \mathrm{P}$ orthophosphate

preparations of ribosomes as described in Methods (figure 3)

used in this discussion to mean RNA extracted from cytoplasmic ribosomes. This would include ribosome associated RNA

used in this discussion as a collective term to describe both single (monosomes) and multiple ribosomal units (polysomes)

hepatic rough endoplasmic reticulum

Svedberg unit; a sedimentation constant expressed in reciprocal seconds (IS $=10^{-13} \mathrm{sec}$.)

hepatic smooth endoplasmic reticulum oxidized (reduced) triphosphopyridine nucleotide

ix 


\section{INTRODUCTION}

The endoplasmic reticulum (ER) in rat liver is seen in electron micrographs as a laminar membrane system that courses through the cytoplasm of the cell (Claude, 1969). Portions of the ER are studded with ribosomes and are designated as the rough endoplasmic reticulum ( $R E R$ ); the remainder of the ER is devoid of ribosomes and in the adult rat is closely associated with glycogen particles (Dallner et al., 1966a; 1966b). This portion is termed the smooth endoplasmic reticulum (SER). Recent investigations have shown that these two segments of the ER are involved in a variety of biochemical processes. For example, the bulk of cellular protein synthesis occurs on the ribosomes of the RER (although proteins are synthesized in other organelles and by ribosomes that are not associated with membranes (McCarty et al., 1966; Campbell et al., 1968; Truman et al. , . 1962). There is evidence that some proteins, such as serum albumin, are made exclusively on these membrane bound ribosomes (Redman, 1969); however, a variety of proteins are made in the RER including proteins for other organelles [histones (Gallwitz et al., $1969 \mathrm{a} ; 1969 \mathrm{~b})$, cytochrome c (Campbell et al., 1968)], for the soluble phase of the cell [serine dehydrase (Pitot, 1968)], for the ER [TPNH cytochrome c reductase (Campbell et al., 1968)] as well as for export into the plasma [lipoproteins (Claude, 1968). albumin (Redman, 1969)]. Recent evidence also exists that hepatic and serum glycoproteins are made exclusively on bound ribosomes (Lawford et al., 1966; Hallinan et al., 1968). 
Aside from its role in protein synthesis, the ER has a large number of catalytic functions. One of these functions is the hydroxylation of a wide variety of substrates including steroids, drugs, carcinogens and omega oxidation of lipids (Gillette, 1963; Preiss et al., 1964). These hydroxylations are catalyzed by enzymes that have been termed "mixed function oxidases" as a consequence of the fact that one atom of molecular oxygen is incorporated into the substrate (Mason, 1965). This enzyme system shows a strong requirement for reduced triphosphopy ridine nucleotide (TPNH), and the overall reaction sequence can be described as follows:

$$
\mathrm{RH}+\mathrm{TPNH}+\mathrm{H}^{+}+\mathrm{O}_{2} \longrightarrow \mathrm{R}-\mathrm{OH}+\mathrm{TPN}^{+}+\mathrm{H}_{2} \mathrm{O}
$$

The ER also contains two electron transport chains (Siekevitz, 1965); one accepts electrons from reduced diphosphopyridine nucleotide. (DPNH) and has no known function (Strittmatter, 1965). The other electron transport system accepts electrons from TPNH through a cytochrome c reductase (Kamin et al., 1965) and transfers them by an undefined intermediate (active cytochrome $c$ is not thought to be present in microsomes) to a carbon monoxide (CO) sensitive pigment designated as cytochrome P-450 (Omura, 1965). The TPNH chain has been related to microsomal hydroxylations since these oxidations are inhibited by CO (Omura, 1965) and since drugs cause spectral shifts in P-450 absorbance [ presumably as a result of binding to the pigment (Schenkman et al., 1967)]. More recently the TPNH chain has been partially purified from microsomes and reconstituted; this system (a cytochrome c reductase, P-450 and lipids) has been shown to catalyze the omega hydroxylation of laurate in the presence of TPNH and $\mathrm{O}_{2}$ and to produce the expected spectral shifts in the presence of drugs ( Lu et al., 1969; Coon et al., 1969). As well as hydroxylations, the ER catalyzes a variety of reactions including 
biological reductions, conjugations and contains an ATPase, a monoamine oxidase, phosphatases, pyrophosphatases and other enzymes as well as the marker enzymes, glucose-6-phosphatase and nucleotide ¿iphosphatase (Gillette, 1963).

Besides being active in the steady state metabolism of the liver, the ER has been shown to be important in the response of the liver to external influences such as hormones and drugs ( Tata, 1967). Phenobarbital is one of the agents that shows dramatic effects on the ER. Rats treated several days with hypnotic doses of phenobarbital show a sequential increase in, first, RER and then a more extensive increase in SER (Staubliet al., 1969). This increase in SER is paralleled by increased microsomal protein (Ernster et al., 1965) and phospholipid (Orrenius, 1968a) and increased activity in some of the microsomal enzymes (figure 1) particularly the mixed function oxidases, at the expense of other activities (Ernster et al., 1965) such as glucose-6-phosphatase and nucleotide diphosphatase. The increase in microsomal protein is accompanied by an increase in li.ver weight (figure 2) (Shuster et al., 1966). Since the increased enzyme activities and SER proliferation are blocked by protein synthesis inhibitors such as actinomycin D, puromycin (Orrenius et al., 1965), and ethionine (Kato et al., 1962) and since phenobarbital stimulates the incorporation of radioactive precursors into microsomal protein in vivo (Kato et al., 1965) and in vitro (Kato et al., 1966), it has been suggested that the microsomal response is due to de novo synthesis of protein. Although there is much evidence to support this conclusion, it has also been suggested by several investigators that phenobarbital treatment reduces the rate of degradation of microsomal protein and lipid and that the altered degradation rate may play a role in the hepatic response to the barbiturate (Jick et al., 1966; Orrenius et al., 1968a; Kuriyama et al., 1969). 
Figure 1

The Effect of Pretreatment with Phenobarbital on the In Vitro Demethylation of Aminopy rine

Two rats were treated with either $80 \mathrm{mg} / \mathrm{kg}$ phenobarbital or an equal volume of saline daily for three days. The $10,000 \mathrm{Xg}$ supernatants were prepared and protein equivalent to $100 \mathrm{mg}$ liver was incubated for the indicated times, in the following mixture:

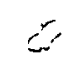

25 rmoles $\mathrm{MgCl}_{2}$

100 moles nicotinamide

10 umoles semicarbazide

1 mole triphosphopyridine nucleotide (ox)

25 moles glucose-6-phosphate

25 moles aminopyrine and,

$0.1 \mathrm{M}$ phosphate buffer to bring the final volume to four milliliters

Aminopyrine demethylation was measured by the Nash formaldehyde determination (Nash, 1953 ). 


\section{PHENOBARBITAL PRETREATMENT ON IN VITRO}

DEMETHYLATION OF AMINOPYRINE

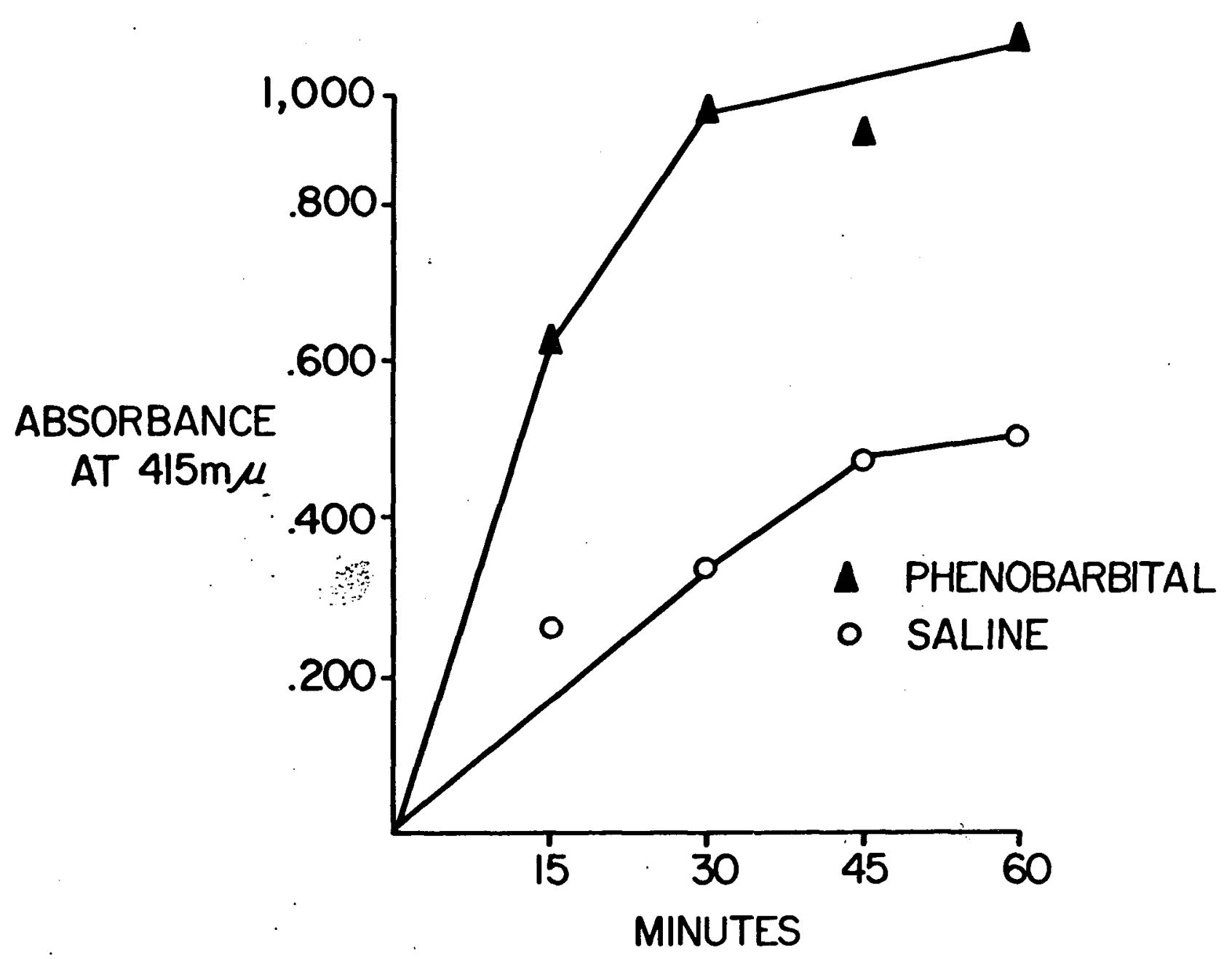




\section{Figure 2 .}

The Effect of Phenobarbital Treatment on Liver W eight and Microsomal Protein

Rats were treated twice daily with $80 \mathrm{mg} / \mathrm{kg}$ phenobarbital or an equal volume of saline for four days. On indicated days three rats in each group were killed and liver weight was determined by volume displacement and the protein in the microsomal pellet was estimated by the biuret method (Gornall et al., 1949). These data are plotted as (a) liver weight and, (b) microsomal protein per liver; each point represents the average of three determinations. 
EFFECT OF PHENOBARBITAL ON LIVER WEIGHT

\& MICROSOMAL PROTEIN CONTENT
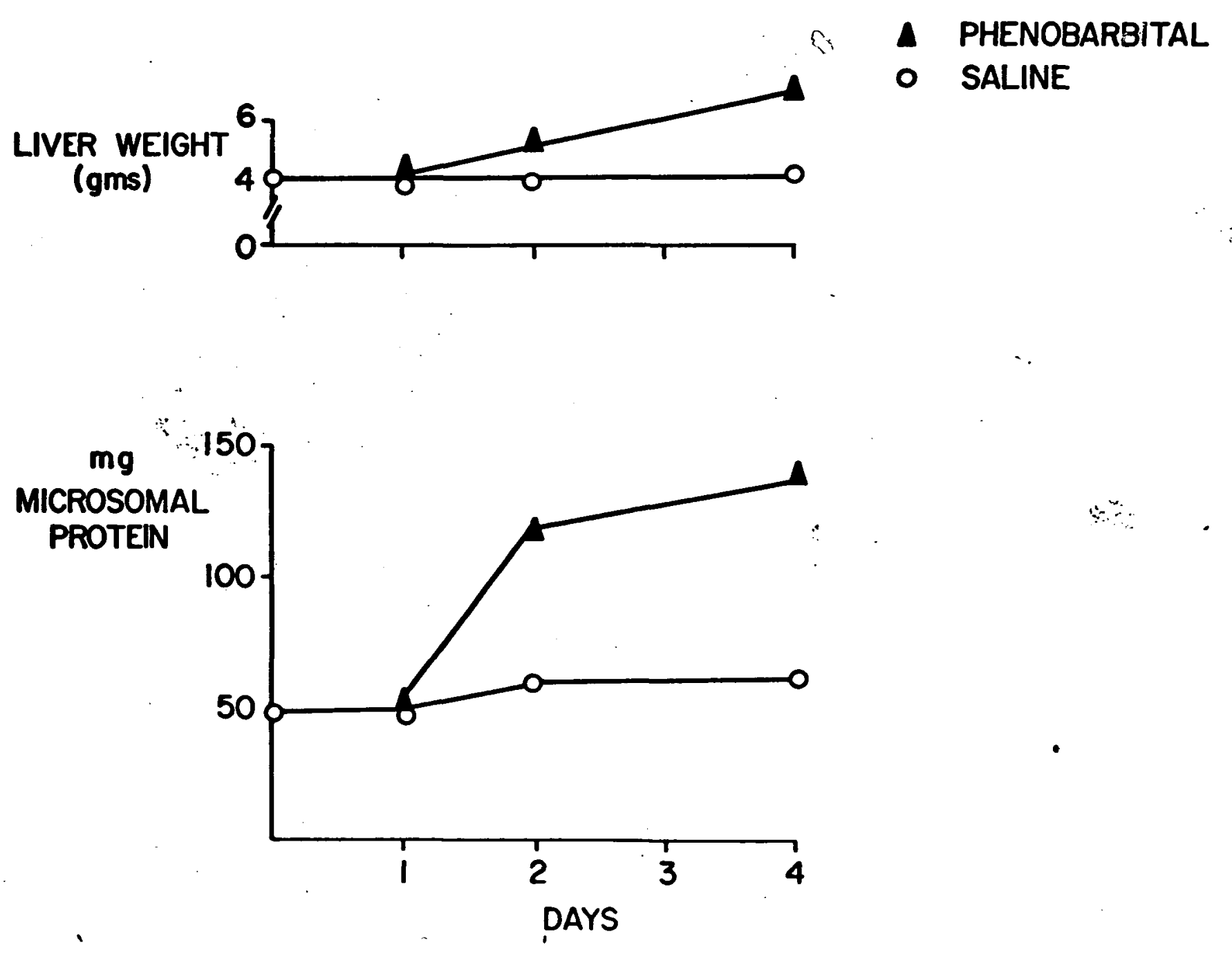
Investigations (Orrenius et al., 1968a) with ${ }^{32} \mathrm{P}$ phosphate and ${ }^{14} \mathrm{C}$ ethanolamine incorporation into microsomal phospholipid have indicated that phospholipid synthesis may be an early event after the administration of phenobarbital. However, other investigators have not been able to repeat these experiments with either radioactive phosphate or glycerol (Holtzman et al., 1968; Omura et al., 1969). It has also been suggested that the rate of degradation of phospholipids is slowed after phenobarbital treatment (Orrenius et al. , 1968a; Holtzman et al, , 1968). One possible explanation for the conflicting data concerning phenobarbital's effect on microsomal phospholipid was proposed by Omura (1969); it is possible that the apparent ${ }^{32} \mathrm{Pi}$ and ethanolamine "incorporation" may be due to the transesterification of phospholipids instead of their synthesis.

Although a good deal of investigation has been directed towards the effect of several sequential treatments with phenobarbital, relatively few experiments have been concerned with early events (within the first twenty-four hours) (Orrenius et al., 1968b; Kuriyama et al., 1969) after treatment. Since these early effects may be indicative of the initial action of phenobarbital, and, be of some interest in defining both the mechanism of action of an anabolic agent on the liver and some aspects of membrane biosynthesis, the present investigation is directed towards biochemical events that occur within twenty-four hours after a single dose of the drug. The fact that phenobarbital increased total microsomal protein as well as the rate of incorporation of amino acids into microsomal protein (Kato, 1965), and that inhibitors of protein synthesis prevented these increases, indicated that phenobarbital may have an early influence on protein synthesis. It has also been observed that phenobarbital treatment increases the activity of the nuclear DNA dependent RNA polymerase (Orrenius, 1968b). These observations indicated that RNA may play 
a role in the hepatic response to phenobarbital. In order to examine the primary events after treatment with phenobarbital, it was necessary to determine when the cell began to show a major anabolic response to the drug and then to investigate the events that led to this response. On the assumption that the dramatic changes in liver metabolism were due to biosynthetic processes, and that these processes would put an unusual demand for energy on the cell, adenine nucleotide concentrations and the turnover of ATP were measured with the anticipation that they would indicate a major energy demanding process such as an increase in protein synthesis. After finding an alteration in adenine nucleotide metabolism, investigations were directed toward the description of events that might precede, and result in, an increased utilization of cellular energy for biosynthetic purposes. These studies were primarily concerned with the synthesis of RNA and appearance of RNA in the cytoplasm, with its species and subcellular distribution, and with factors that controlled this RNA (intracellular and hormonal). Finally an attempt was made to correlate the activity of the RNA with respect to protein synthesis and the alterations in the adenine nucleotide pool caused by phenobarbital treatment. It is hoped that the interpretation of this data, in the light of the available literature, will contribute to understanding the processes that lead to synthesis of membrane bound proteins as well as the mechanism of the hepatic response to phenobarbital. 


\section{METHODS}

\section{Treatment of Animals}

Male rats of the Wistar strain ( $100-175 \mathrm{~g})$ were used for all experiments; animals were fasted for 12-18 hours before sacrifice. When indicated, animals were bilaterally adrenalectomized under ether anesthesia three days before gacrifice. Adrenalectomized rats were maintained on $0.9 \% \mathrm{NaCl}$ in their drinking water. All drug injections were made by the intraperitoneal route and controls were administered an equal volume of saline. Radio-isotopes were injected by tail vein under light ether anesthesia. In all instances, anesthesia was induced in a chamber in which an ether and air mixture was introduced by a bubbling chamber. Except in the case of measurement of adenine nucleotide turnover, tail vein injections were made immediately after induction of anesthesia. In order to maintain onstant anesthesia over the short labeling time with ${ }^{32} \mathrm{P}$ phosphate, and to permit in situ sampling, it was necessary to maintain animals, in which nucleotide measurements were being made, in a $100 \%$ oxygen and ether mixture in the apparatus described by Bucher and Swaffield (1966). This method of anesthesia was found to eliminate variation seen in animals anesthetized by other methods ( since the possibility of hepatic hypoxia was reduced).

All injections were made with sterile saline ( Travenol) as a diluent. Phenobarbital was given in a dose of $8 \mathrm{mg} / 100$ gram body weight; cycloheximide $50 \mu \mathrm{g} / 100 \mathrm{~g}$ (Yeh et al., 1969). 
${ }^{24} \mathrm{C}$ orotate was given in doses of 4 and $8 \mu \mathrm{c}$ per rat. ${ }^{14} \mathrm{C}$ leucine and ${ }^{32} \mathrm{P}$ (high specific activity) were given in doses of $5 \mu \mathrm{C}$ and 10 $\mu c$ per rat respectively.

Estimation of ATP, ADP, AMP, DNA and ${ }^{32} \mathrm{Pi}$ Incorporation into $\underline{\text { ATP }}$

In order to estimate ATP turnover, rats were anesthetized in a mixture of ether and $100 \%$ oxygen by the method of Bucher and Swaffield (1966) and $10 \mu \mathrm{c}$ of ${ }^{32} \mathrm{P}$ phosphate $\left({ }^{32} \mathrm{Pi}\right)$ was injected by tail vein. In order to eliminate the prospect of pyrophosphate contamination, the ${ }^{32} \mathrm{Pi}$ solution was boiled for 10 minutes in $1 \mathrm{~N} \mathrm{HCl}$ and neutralized before use. Five minutes after injection a sample $(200-300 \mathrm{mg})$ of the left lateral hepatic lobe was frozen in situ with modified Wollenberger clamps that had been cooled in liquid nitrogen, and then immediately plunged into liquid nitrogen. The tissue sample was then rapidly homogenized in a ground-glass conical homogenizer in $5 \mathrm{ml}$ ice cold $5 \%$ perchloric acid (PCA). A $3 \mathrm{ml}$ aliquot was added to $1 \mathrm{ml} 20 \%$ Norite $A$ and allowed to stand five minutes at $0^{\circ} \mathrm{C}$. The charcoal was washed three times with water and the adsorbed adenine nucleotide phosphate was hydrolyzed in $1 \mathrm{~N} \mathrm{HCl}$ at $100^{\circ} \mathrm{C}$ for ten minutes and centrifuged. The supernatant was neutralized with $\mathrm{NaOH}$ and radioactivity determined by liquid scintillation counting. Phosphate was estimated by the method of Fiske and Subbarow (1929). Treatment of samples in this manner has been shown to be essentially a measurement of $\gamma$ phos phate of ATP (Ove et al., 1967). The results are expressed as counts/minute/micromole of phosphate.

Adenine nucleotide concentrations were measured in the perchloric acid supernatant of a similarly obtained liver sample. The supernatant was neutralized with potassium hydroxide and buffered 
with $0.05 \mathrm{M}$ tris at $\mathrm{pH}$ 7.5. The concentrations of adenine nucleotides were measured spectrophotometrically by coupled enzymatic reactions. ATP and ADP were measured by the method of Kornberg and Pricer (1951), and Kornberg (1950), respectively, and AMP by Lowry's method ( 1964 ), adapted for spectrophotometry. The residue after the perchloric acid extraction was used for estimation of DNA (Burton, 1955) and nucleotide data was expressed as $\mu \mathrm{moles} / \mathrm{mg}$ DNA.

\section{Tissue Preparations}

In order to perform the experiments described below, a variety of tissue preparations were used. These preparations are summarized in figure 3 and their preparation is described below. Lower case letters refer to lettered paragraphs in this section.

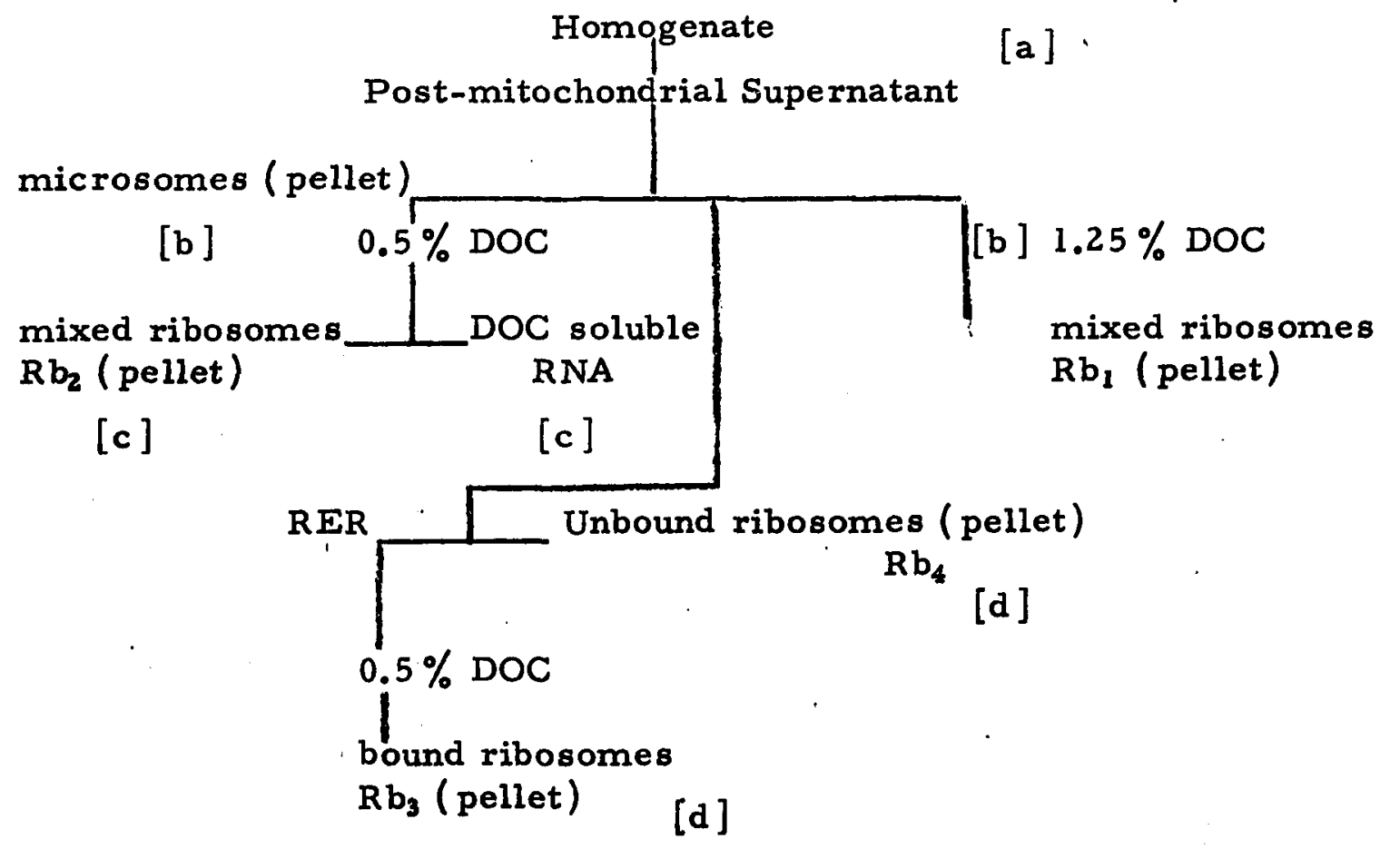

\section{Figure 3}

Preparation of Tissue Fractions 
All tissue preparations were handled at $4^{\circ} \mathrm{C}$.

[a] Homogenates were prepared by passing either single or several livers (in the instances when livers were pooled) through a Harvard tissue press. The pressed liver was then homogenized with a teflon-glass Potter-Elvehjëm. homogenizer in 2-4 volumes of Medium A of Littlefield et al. (1957). Post-mitochondrial supernatants were prepared by centrifuging the homogenate at $15,000 \times \mathrm{g}$ for 10 minutes.

[b] Post-mitochondrial supernatants were used for the preparation of microsomes by spinning at $100,000 \times \mathrm{g}$ for $60 \mathrm{~min}$ utes. The resulting pellet after decanting supernatant and wiping the upper portion of the centrifuge tube was resuspended by gentle homogenization in Medium A. The post-mitochondrial supernatant was also used in the preparation of mixed ribosomes by the method of Webb et al. (1964). The post-mitochondrial supernatant was brought to $1.25 \%$ desoxycholate (DOC), and 4 milliliters of the DOC treated supernatant were layered over a discontinuous sucrose gradient $(2.5 \mathrm{ml}$ each of $0.5 \mathrm{M}$ and $2.0 \mathrm{M}$ sucrose; containing 0.005 $\mathrm{M} \mathrm{MgCl} 2,0.005 \mathrm{M} \mathrm{KCl}, 0.05 \mathrm{M}$ Tris $\mathrm{pH} 7.4$ ) and centrifuged at 40,000 rpm for 200 minutes in a No. 50 rotor in a Spinco L2 ultracentrifuge. A pinkish pellet was collected after the centrifuge tube was drained and wiped. This pellet was resuspended in Medium $A$ and is designated as the $R b_{1}$ fraction. In one experiment the $R b_{1}$ fraction was subjected to density gradient analysis as described in figurs 8. It is clear that most of the RNA is in the form of polysomes in both phenobarbital and saline treated animals; however, a single peak probably representing monosomes is also observed in both gradients.

[c] A second mixed ribosome fraction was prepared from the microsomal fraction. This fraction was prepared by treating the 
microsomal suspension with $0.5 \%$ DOC, inverting twice and then centrifuging at $100,000 \times \mathrm{g}$ for 60 minutes. The pellet from this centrifugation which represents mixed ribosomes, and was suspend-' ed in Medium $A$, is referred to as the $R b_{2}$ fraction. Attempts were made to determine the number of polysomes in the $\mathrm{Rb}_{2}$ fraction; however, this fraction was apparently extensively contaminated with membranes and sedimented through the sucrose gradient. The supernatant fraction from this centrifugation contained a nondializable $260 \mathrm{~m} \mu$ absorbing substance into which radioactivity from orotic acid was found after in vivo administration. Presumably, this is the membrane RNA referred to by other investigators (Gardner et al., 1968; Pitot et al., 1969; Moule, 1968) and is designated here as DOC-soluble RNA. It is unlikely that DOC-soluble RNA is ribosomal RNA that has contaminated the DOC supernatant since in rats labelled with ${ }^{14} \mathrm{C}$-orotate, ribosomal $\mathrm{RNA}$ had lower specific activity than the DOC soluble RNA ( see Table 5). However, it is not possible from the data reported here to say with complete certainty what type of RNA is found in the DOC supernatant of microsomes; furthermore, the possibility (although unlikely) exists that the $260 \mathrm{m \mu}$ absorbance and the radioactivity from the orotate precursor are in separate, ṇon-dialyzable molecules.

[d] The post-mitochondrial supernatant was used to prepare free and bound ribosomes by a modification of the method of Bloemendal et al. (1967). RER and free ribosomes are prepared by centrifugation of the post-mitochondrial supernatant through a discontinuous sucrose gradient $(2.5 \mathrm{ml}$ each of $1.5 \mathrm{M}$ and $2.0 \mathrm{M}$ sucrose containing $0.005 \mathrm{M} \mathrm{MgCl}_{2}, 0.025 \mathrm{M} \mathrm{KCl}$ and $0.05 \mathrm{M}$ Tris pH 7.4) at 44,000 rpm for 200 minutes in a No. 50 rotor in a Spinco L2 ultracentrifuge. The RER was collected by removing "band 3 " (Bloemendal et al., 1967) with a bent Pasteur pipette. Band 3 is 
the interface between the $1.5 \mathrm{M}$ and $2.0 \mathrm{M}$ sucrose. The free ribosomes were found as a pellet underneath the $2.0 \mathrm{M}$ sucrose. This pellet was resuspended in Medium $A$ and designated as the $R_{4}$ fraction. Band 3 was resuspended in water to bring the concentration of sucrose to $0.25 \mathrm{M}$ and brought to $0.5 \%$ DOC. The bound ribosomes were collected by centrifugation at $100,000 \times \mathrm{g}$ for 60 minutes, resuspended in Medium $A$ and designated as the $R b_{3}$ fraction.

Extraction of RNA

During the course of the experiments described below, RNA was extracted from several tissue fractions as described by VillaTrevino et al. (1966), and its specific activity, after in vivo administration of radioactive orotic acid, was determined. The appropriate tissue fraction was prepared, as described above, from a single or pooled livers. The fraction was then made $0.1 \%$ with sodium dodecyl sulfate (SDS) and extracted with vigorous shaking for sixty minutes at room temperature in an equal volume of redistilled, water saturated phenol. The usual volume of a tissue preparation extracted by this method was between ten and twenty milliliters, and the extraction was performed in glass stoppered tubes. After extraction, the tubes were chilled in ice and centrifuged at 2,000 rpm for twenty minutes to separate the aqueous and phenol phases. A volume (usually 5-10 ml) was pipetted from the aqueous phase and one-tenth volume of $20 \%$ potassium acetate ( $\mathrm{pH} 5.1$ ) was added; the RNA was then precipitated with two and one half volumes of absolute ethanol at $-20^{\circ} \mathrm{C}$ for at least twelve hours. The addition of potassium acetate proved to be quite important to the precipitation of small quantities of RNA. The precipitated RNA was collected by centrifugation and dissolved in cold water. 
Since the concentration of RNA was estimated by $260 \mathrm{~m} \mu$ absorbance ( $1 \mathrm{mg}$ RNA $=20.0$ absorbance units), it was important to remove phenol that contaminated the RNA pellet as completely as possible. The phenol was removed by two methods. An aqueous RNA solution was either washed three times with an equal volume of diethyl ether or dialyzed against three changes (fifty volumes) of Medium A. Either method was effective in removing adhered phenol as judged by the decrease in the absorbance of phenol at 270 mp; however, ether extracted RNA had a consistently higher specific activity indicating that this method may be more effective in removing phenol. In any event, this difference did not affect the relationship of experimental animals to their controls.

Although the rats were fasted for twelve to eighteen hours and this usually minimized the contamination of the extracted RNA with glycogen, occasionally, contamination with glycogen became a problem (particularly when larger amounts of tissue were extracted). In these instances, the sample appeared opalescent and $260 \mathrm{m \mu}$ absorbance was unusually high as a result of light scattering. Glycogen was removed by centrifugation at $100,000 \times \mathrm{g}$ for sixty minutes and the clear supernate containing RNA was decanted; the glycogen pellet was discarded (Dingman et al., 1962).

Radioactivity in RNA was estimated by scintillation counting of the aqueous RNA solution. Specific activity is expressed as cpm in RNA/mg RNA.

Binding of $\mathrm{Rb}_{1}$ to "Stripped" RER

RER was isolated by the method of Bloemendal et al. (1967) as shown in figure $3 \mathrm{~d}$, and stripped of ribosomes as described by Suss et al. (1966). This latter method consisted of washing the RER (by resuspension) in $0.01 \mathrm{M}$ sodium pyrophosphate, followed by 
several washes with $0.2 \mathrm{M}$ sodium pyrophosphate, followed by several washes with $0.2 \mathrm{M}$ sucrose. The membranes were then resuspended in a "stripping buffer" which contained $0.25 \mathrm{M}$ sucrose, $0.08 \mathrm{M}$ sodium citrate, $0.01 \mathrm{M}$ sodium pyrophosphate and $0.01 \mathrm{M}$ $\mathrm{Na}-\mathrm{K}$ phosphate at $\mathrm{pH} 7.4$ and incubated for 30 minutes at $0^{\circ} \mathrm{C}$. The membranes were then collected by centrifugation in $1.7 \mathrm{M}$ sucrose. These floating membranes were resuspended and stored as described by Suss et al. (1966) until use. During the stripping process the 280/260 ratio of the membranes changed from approximately 0.70 to 0.86 , indicating that about $50 \%$ of the RNA was removed (Warburg and Christian, 1941).

The $R b_{1}$ fraction was prepared as described in figure $3 \mathrm{~b}$, 12 hours after the administration of $8 \mu \mathrm{c}{ }^{14} \mathrm{C}$ orotate and was used for binding to the membrane (Suss et al., 1966). In the binding experiments, $0.64 \mathrm{mg}$ of stripped membrane and radioactive $R b_{1}$ fraction (100-850 $\mathrm{\mu g}$ RNA) were shaken by hand for 20 seconds and then incubated at $0^{\circ} \mathrm{C}$ for 30 minutes in $0.2 \mathrm{M}$ sucrose made $20 \%$ with liver supernatant fraction. The reconstituted membrane was collected by centrifugation over a discontinuous gradient $(0.5 \mathrm{M}$ sucrose over $2.0 \mathrm{M}$ sucrose) and removed from the $2.0 \mathrm{M}$ sucrose interface by use of a bent Pasteur pipette. Radioactivity and protein concentration were determined from the resuspended membrane. Data were expressed as counts per minute $(\mathrm{cpm})$ per $\mathrm{mg}$ protein; however, since the $R b_{1}$ fraction from phenobarbital treated rats had a higher specific activity than its control (e.g., in one experiment phenobarbital $R b_{1}=32,000 \mathrm{cpm} / \mathrm{mg} R N$ and saline $R b_{1}=26,000$ cpm/mg RNA) it was necessary to also express the data as $\mu g$ RNA/ mg membrane protein. It must be pointed out that this expression is only valid when the assumption is made that the specific activity of the whole $R b_{1}$ fraction is representative of the bound RNA. 
Measurement of Incorporation of ${ }^{14} \mathrm{C}$ Leucine into Radioactive Ribosome Bound Peptides

In one experiment, the rate of incorporation of radioactive leucine into ribosomal peptides was estimated. In order to perform this experiment a $5 \mu \mathrm{c}$ dose of ${ }^{14} \mathrm{C}$ leucine was pulsed for 5 minutes (Redman, 1969; Cox et al., 1969) in vivo; the rats were killed and the $R b_{2}, R b_{3}$ and $R b_{4}$ fractions were isolated. These fractions were made $5 \%$ with perchloric acid (PCA) and washed three times with $5 \%$ PCA. The resulting precipitate was dissolved in $0.5 \mathrm{~N} \mathrm{NaOH}$. Aliquots were taken for scintillation counting and estimation of $260 \mathrm{~m} \mu$ absorbance. Data was expressed as cpm in protein/mg RNA on the assumption that 20.0 absorbance units were the equivalent to $1 \mathrm{mg}$ of RNA.

\section{Estimation of the Synthesis of Nuclear RNA}

In one series of experiments, the synthesis rate of nuclear RNA was estimated. In order to conveniently estimate this rate, the specific activity of cellular RNA was estimated after a twenty minute pulse of orotic acid. It has been demonstrated by Hiatt (1962) that very little RNA has entered the cytoplasm during,this time period. Thus, this measurement reflects the synthesis rate of nuclear RNA without significant influence of transport to the cytoplasm on this rate.

In these experiments, rats were injected by tail vein with 4 Mc of radioactive orotic acid and killed twenty minutes later. RNA was extracted from the homogenate as previously described and the specific activity was estimated. 
Estimation of the Half Life of Microsomal RNA

In one experiment, the degradation of microsomal RNA was estimated. Rats were injected with radioactive orotic acid and eight hours later repetitive doses (every twelve hours) of phenobarbital or saline were administered. Daily, for four days, three rats in each group were killed and their whole livers carefully excised, weighed and homogenized in two volumes of Medium A. The final volume of the homogenate was recorded. A measured volume was then used to prepare a microsomal pellet as described in Methods. This pellet was resuspended in a volume of Medium $A$ equivalent to the volume of homogenate used to prepare the pellet. A measured volume of the microsomal suspension was then subjected to a modification of the Schmidt-Thannhauser extraction procedure (1945) as described below. The volume of microsomal suspension was mixed with an equal volume of $10 \% \mathrm{PCA}$ and the pellet collected by centrifugation. The pellet was subsequently washed twice with $5 \%$ PCA, and the final wash was counted to insure that radioactivity not in RNA was removed. The washed pellet was incubated for one hour in $4.5 \mathrm{ml} 0.3 \mathrm{~N} \mathrm{NaOH}$ and precipitated with $0.5 \mathrm{ml} 70 \%$ PCA. Radioactivity was estimated in this supernatant fraction and total radioactivity per liver was calculated from the recorded dilutions.

Measurement of Radioactivity and other Analytical Methods Radioactivity of ${ }^{32} \mathrm{P}$ and ${ }^{14} \mathrm{C}$ compounds was measured by liquia scintillation counting according to Bray (1960) in a Packard Tri Carb liquid scintillator. All solutions subjected to scintillation counting were in neutral aqueous solution. Since quenching of the fluorophores was not a problem, data is expressed as counts per minute. 
Protein concentration was estimated by the Lowry phenol method (Lowry et al. , 1951) or the biuret method (Gornall et al., 1949). Plasma corticosterone was estimated by the method of Moncloa et al. ( 1959$)$.

At the appropriate times, the uptake of radiolabeled compounds by liver was estimated. In experiments with radioactive orotic acid and leucine, counts that remained in the supernate of homogenates made $5 \%$ with perchloric acid were estimated and expressed as cpm/260 mp absorbance unit or as $\mathrm{cpm} / \mathrm{gram}$ wet weight respectively. Uptake of ${ }^{32} \mathrm{P}$ phosphate was estimated by estimating counts not adsorbed to charcoal. These data were expressed as cpm/umole phosphate. Under the conditions of these experiments, the uptake of isotopically labeled compounds was unaffected by phenobarbital treatment.

\section{Materials}

Phenobarbital was purchased from Intra Products, Inc. of Dayton, Ohio.

Cycloheximide (Acti-dione) was obtained from the Upjohn Company in Cincinnati, Ohio. This drug as supplied is $80 \%$ purecs

With the exception of lactate dehydrogenase, enzymes (Hexokinase, glucose-6-phosphate dehydrogenase, pyruvate kinase and myokinase) and nucleotide cofactors (adenine nucleotides and nicotinamide adenine dinucleotides) and substrates were purchased from Sigma Chemical Company. Lactate dehydrogenase was the product of Gallard-Schlesinger Chemical Manufacturing Corporation, Long Island, New York. All enzymes were purchased in the highest purity available. 
$\left[{ }^{14} \mathrm{C}-6\right]$ orotic acid $(7 \mathrm{mC} / \mathrm{m}$ mole $)$ and ${ }^{14} \mathrm{C}-\mu$-leucine $(240 \mathrm{mC} / \mathrm{m}$ mole) were obtained from New England Nuclear, Inc., Boston, Massachusetts. ${ }^{32} \mathrm{P}$ phosphate was the generous gift of Dr. Riccobono, Department of Radiology, College of Medicine, The Ohio State University.

Travenol is the product of Travenol Laboratories, Inc., Morton Grove, Illinois. 


\section{RESULTS}

Estimation of Adenine Nucleotide Levels and ATP Turnover in Rat Liver and Its Relationship to the Adrenal Cortex

Since phenobarbital has a marked anabolic effect on the liver, and since the major anabolic events reported by other investigator 8 are ATP-requiring processes (protein and phospholipid synthesis), it was decided to investigate the effect that drug treatment might have on the concentration and turnover of the adenine nucleotides. It was hoped that an alteration in the metabolism of the adenine nucleotides would serve as a marker for the initiation of major biosynthetic events after phenobarbital treatment. Once such a marker was discovered, it would be possible to investigate the more subtle events that cause the dramatic metabolic changes that are caused by phenobarbital.

The concentrations of the three adenine nucleotides, ATP, $A D P$ and AMP, were determined at several time intervals in the livers of intact and adrenalectomized male rats after a single injection of phenobarbital or an equal volume of saline. The untreated control determinations ( Table 1) are comparable to previously reported values expressed in the same manner (Ove et al., 1968; Okazaki et al., 1968). At the time intervals selected, there was no difference between intact and adrenalectomized phenobarbital treated rats and their saline treated controls in the levels of any of the three nucleotides. It was concluded that over the first twelve hours of phenobarbital treatment that there were no major alterations in the concentrations of the adenine nucleotides. 
Table 1

The Effect of Phenobarbital on the Adenine Nucleotide Content of Rat Liver

\begin{tabular}{lcccc}
\hline Treatment & $\begin{array}{c}\text { Hrs. after } \\
\text { Treatment }\end{array}$ & $\begin{array}{c}\text { ATP/mg } \\
\text { DNA }\end{array}$ & $\begin{array}{c}\text { ADP/mg } \\
\text { DNA }\end{array}$ & $\begin{array}{c}\text { AMP/mg } \\
\text { DNA }\end{array}$ \\
\hline Untreated control (9) & 0 & 1.09 & 0.58 & 0.35 \\
INTACT & & & & 0.28 \\
$\quad$ phenobarbital (3) & 2 & 0.96 & 0.37 & 0.46 \\
saline (2) & 2 & 0.87 & 0.47 & \\
INTACT & & & & 0.25 \\
phenobarbital (3) & 6 & & 0.46 & 0.20 \\
saline (2) & 6 & 1.16 & 0.37 &
\end{tabular}

INTACT

$\begin{array}{lllll}\text { phenobarbital (3) } & 12 & 1.70 & 0.79 & 0.37 \\ \text { saline (2) } & 12 & 1.84 & 0.79 & 0.29\end{array}$

ADRENALECTOMIZED

$\begin{array}{lllll}\text { phenobarbital (3) } & 2 & 1.21 & 0.65 & 0.45 \\ \text { saline (3) } & 2 & 1.14 & 0.79 & 0.30\end{array}$

ADRENA LECTOMIZED

$\begin{array}{lllll}\text { phenobarbital (2) } & 6 & 0.99 & 0.47 & 0.43 \\ \text { saline (3) } & 6 & 0.94 & 0.47 & 0.44\end{array}$

Phenobarbital $(80 \mathrm{mg} / \mathrm{kg})$ was given intraperitoneally to intact and bilaterally adrenalectomized $\mathbf{\omega}$ rats and they were killed at the indicated times. Nucleotides were measured as indicated in Methods. Numbers in parenthesis represent number of animals used. 
Although drug treatment did not alter the levels of the nucleotides, the possibility existed that the nucleotides were being used at a greater rate but were being restored to steady state concentrations by increased phosphorylation; that is, the turnover of ATP was increased. In order to investigate this, intact rats were given ${ }^{32} \mathrm{P}$ sodium phosphate $\left({ }^{32} \mathrm{Pi}\right)$ by tail vein at various times after phenobarbital treatment, and the specific activity of the adenine nucleotide phosphate was determined. As can be seen in figure 4, both saline and phenobarbital treatment caused alterations in ATP turnover relative to untreated controls. In rats given either phenobarbital or saline injections, an early peak in ATP turnover was observed at two and six hours (although the response of phenobarbital treated rats was smaller) and had returned to control levels by ten hours. The group of rats treated with saline maintained a level of ATP turnover comparable to the untreated controls throughout the twenty-four hour experimental period. In contrast, rats treated with phenobarbital showed a second peak in ATP turnover at about fourteen hours. This later peak lasted (although somewhat diminished) through twentyfour hours.

Ove et al., 1967, have observed a response in hepatic ATP turnover, similar to the early increase in figure 4, after Celite injection and found that the effect of Celite was prevented by adrenalectomy. These authors concluded that acute stress would increase ATP turnover. In light of these findings, it was decided to investigate the role of the adrenal gland in the ATP turnover caused by saline and phenobarbital injection. The incorporation of ${ }^{32} \mathrm{Pi}$ into adenine nucleotide phosphate was measured, as in figure 4, in adrenalectomized rats that had been treated with either phenobarbital or saline. These data are expressed in Table 2, and it can be seen that neither the early nor late responses were present in the adrenalectomized.rats. Since 
Figure 4

The Effect of phenobartial on ATP Turnover

Intact and bilaterally adrenalectomized rats were injected intraperitoneally with phenobarbital $(80 \mathrm{mg} / \mathrm{kg})$ or saline and killed at the indicated times. Five minutes before sacrifice each rat was injected via tail vein with $10 \mu c{ }^{32} \mathrm{Pi}$. Liver samples were treated as described in methods. Each point represents the average of four to six animals. 
ATP TURNOVER IN PHENOBARBITAL

TREATED RAT LIVER

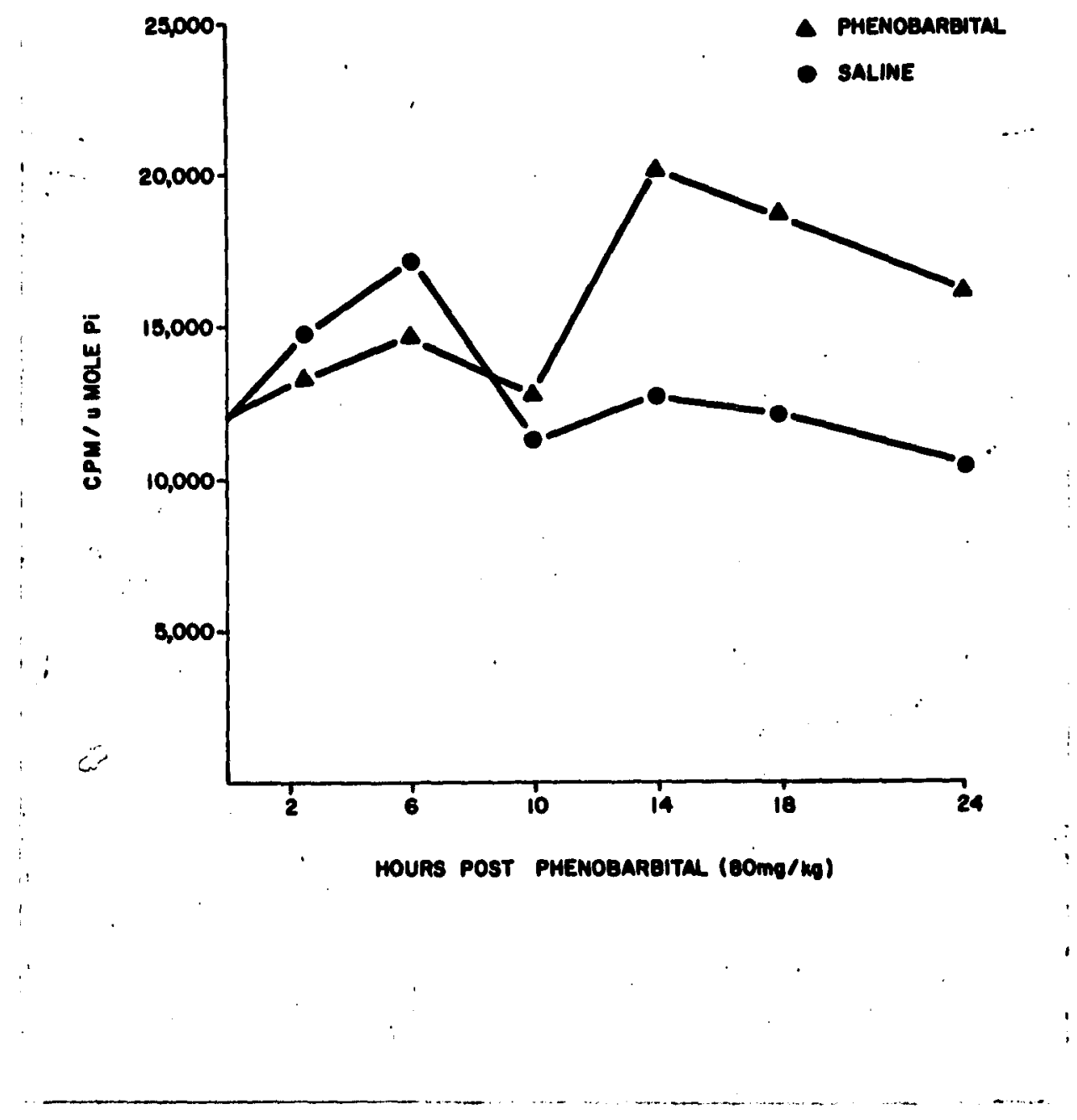


Table 2

The Effect of Phenobarbital on ATP Turnover in Adrenalectomized $R$ ats

\begin{tabular}{lccc}
\hline Treatment & & $\begin{array}{c}\text { Hours after } \\
\text { Treatment }\end{array}$ & $\begin{array}{c}\text { cpm/umole } \\
\text { Pi }\end{array}$ \\
\hline phenobarbital & $(4)$ & 2 & 15,045 \\
saline & $(5)$ & 2 & 14,679 \\
phenobarbital & $(5)$ & 6 & 9,874 \\
saline & $(6)$ & 6 & 11,097 \\
phenobarbital & $(5)$ & 14 & 13,524 \\
saline & $(5)$ & 14 & 13,178 \\
& & 18 & 19,110 \\
phenobarbital & $(3)$ & 18 & 15,906 \\
saline & $(3)$ & 24 & 12,475 \\
phenobarbital & $(3)$ & 24 & 13,092 \\
saline & $(3)$ & & \\
\hline
\end{tabular}

Conditions were $a_{s}$ in figure 4 except animals were bilaterally adrenalectomized. Number in parenthesis represents number of animals used. 
these data are not inconsistent with the influence of the adrenals on the other effects of phenobarbital treatment (Orrenius et al., 1968b), they raised the possibility that the hepatic response to phenobarbital may be an indirect result of the action of the barbiturate on either the pituitary, the adrenal gland or some higher center regulating adrenal function. If this were the case, one would expect to see higher plasma corticoids in barbiturate treated animals. Estimates of plasma corticosterone were made by Dr. M. Hall in intact rats treated with phenobarbital or saline, and as can be seen from Table 3 , there was no difference between phenobarbital treated animals and their saline controls at either $\$$ ix hours. (early peak) or 14 hours (late peak) after treatment.

The data described in this section indicate that phenobarbital has no early effect on adenine nucleotide concentration; however, marked effects on ATP turnover can be observed. These changes in turnover consist of an early component (present to a greater extent in saline treated rats) and a later component (absent in saline treated rats) that is larger and more prolonged. Both components are prevented by adrenalectomy indicating a relationship to the adrenal gland; however, it is unlikely that the ATP turnover, in phenobarbital treated rats, is the result of an indirect effect on the adrenal cortex since neither peak in these animals is associated with any change in plasma corticosterone compared to their saline controls.

\section{Appearance of RNA in the Microsomal Fraction of Rat Liver}

In light of the well-documented effect of phenobarbital on microsomal protein synthesis, and the possibility that one or both of the peaks in ATP turnover caused by phenobarbital treatment (figure 4) might be related to an increase in protein synthesis, experiments were undertaken to determine if these events were related. One 
Table 3

Effect of Phenobarbital Treatment on Plasma Corticosterone

\begin{tabular}{|c|c|c|c|}
\hline Treatment & $\begin{array}{l}\text { Hrs. after } \\
\text { Treatment }\end{array}$ & 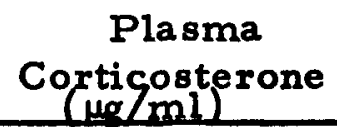 & $\begin{array}{l}\text { Time of } \\
\text { Kill }\end{array}$ \\
\hline $\begin{array}{l}\text { phenobarbital (5) } \\
\text { saline ( } 5)\end{array}$ & $\begin{array}{l}6 \\
6\end{array}$ & $\begin{array}{l}.064 \\
.063\end{array}$ & $\begin{array}{l}2: 00 \text { p. m. } \\
\text { 2:00 p. m. }\end{array}$ \\
\hline $\begin{array}{l}\text { phenobarbital ( } 5 \text { ) } \\
\text { saline ( } 5 \text { ) }\end{array}$ & $\begin{array}{l}14 \\
14\end{array}$ & $\begin{array}{l}.093 \\
.128\end{array}$ & $\begin{array}{l}8: 00 \text { a. m. } \\
8: 00 \text { a.m. }\end{array}$ \\
\hline
\end{tabular}

Phenobarbital $(80 \mathrm{mg} / \mathrm{kg}$ ) was given intraperitoneally to intact rats and they were killed at the times indicated. Plasma corticosterone was estimated as described in Methods. Number of animals used is in parenthesis; each value represents the average of 5 determinations. 
event that might relate the drug caused increases in microsomal protein synthesis and ATP turnover is an increase in microsomal RNA. In order to investigate the effect of phenobarbital on the

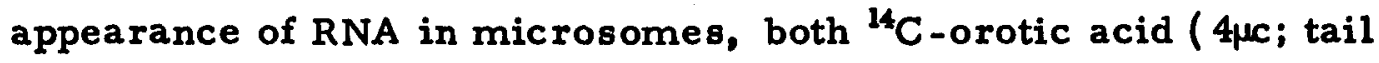
vein) and a single dose of phenobarbital ( $80 \mathrm{mg} / \mathrm{kg}$, i. p. ) were administered simultaneously and the rats were killed at various times thereafter. Microsomes were prepared from the liver, the RNA isolated and the specific activity determined. These data are plotted in figure 5 (also, see Table 6). It can be seen that there is a modest increase in the specific activity ( $120 \%$ at twelve hours) of the RNA that appears in the microsomes of phenobarbital treated rats at twelve and eighteen hours, and then the specific activity returned to control level. It is important to note that this increase is well correlated in time with the fourteen to twenty-four hour increasi in ATP turnover seen after treatment with phenobarbital (figure 4). The increase in specific activity of the microsomal RNA appears at about the same time or preceeds the increase in ATP turnover, and the specific activity of the microsomal RNA has returned to control levels at twenty four hours as the ATP turnover is waning back towards the control level. To provide further evidence for the correlation between ATP turnover and appearance of microsomal RNA it was necessary to determine whether adrenalectomy had any effect on the appearance of RNA in the microsomes. To this end, rats were adrenalectomized and then treated as in figure 5; the specific activity of the microsomal RNA was determined after a twelve hour labeling period. It was found ( Table 4) that adrenalectomy prevented the increased labeling of microsomal RNA thus supporting the conclusion that the appearance of microsomal RNA and the increase in ATP turnover at fourteen through twenty-four hours are related. 
Figure 5

Microsomal RNA in Phenobarbital Treated Rats

Intact rats were injected intraperitoneally with phenobarbital and intravenously with $4 \mu \mathrm{c}$ of ${ }^{14} \mathrm{C}$ orotic acid at zero time and then were killed at the indicated times. Microsomal RNA was prepared as described in Methods from the pooled livers of two rats, and the specific activity determined. Each point represents the average values from four to eight animals. 
32

MICROSOMAL RNA IN

PHENOBARBITAL TREATED RAT LIVER

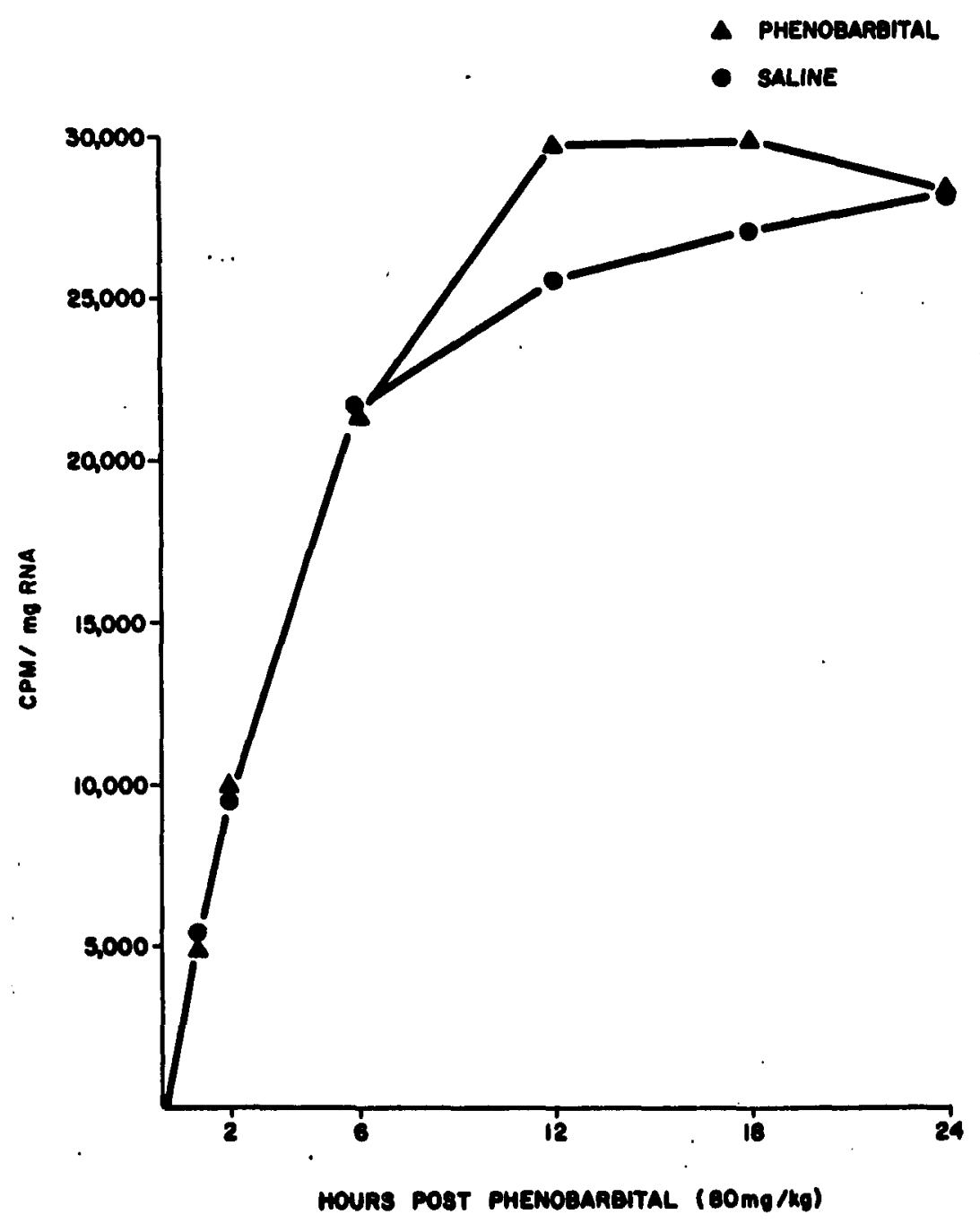


Table 4

The Effect of Phenobarbital on the Appearance of Microsomal RNA in Adrenalectomized Rats

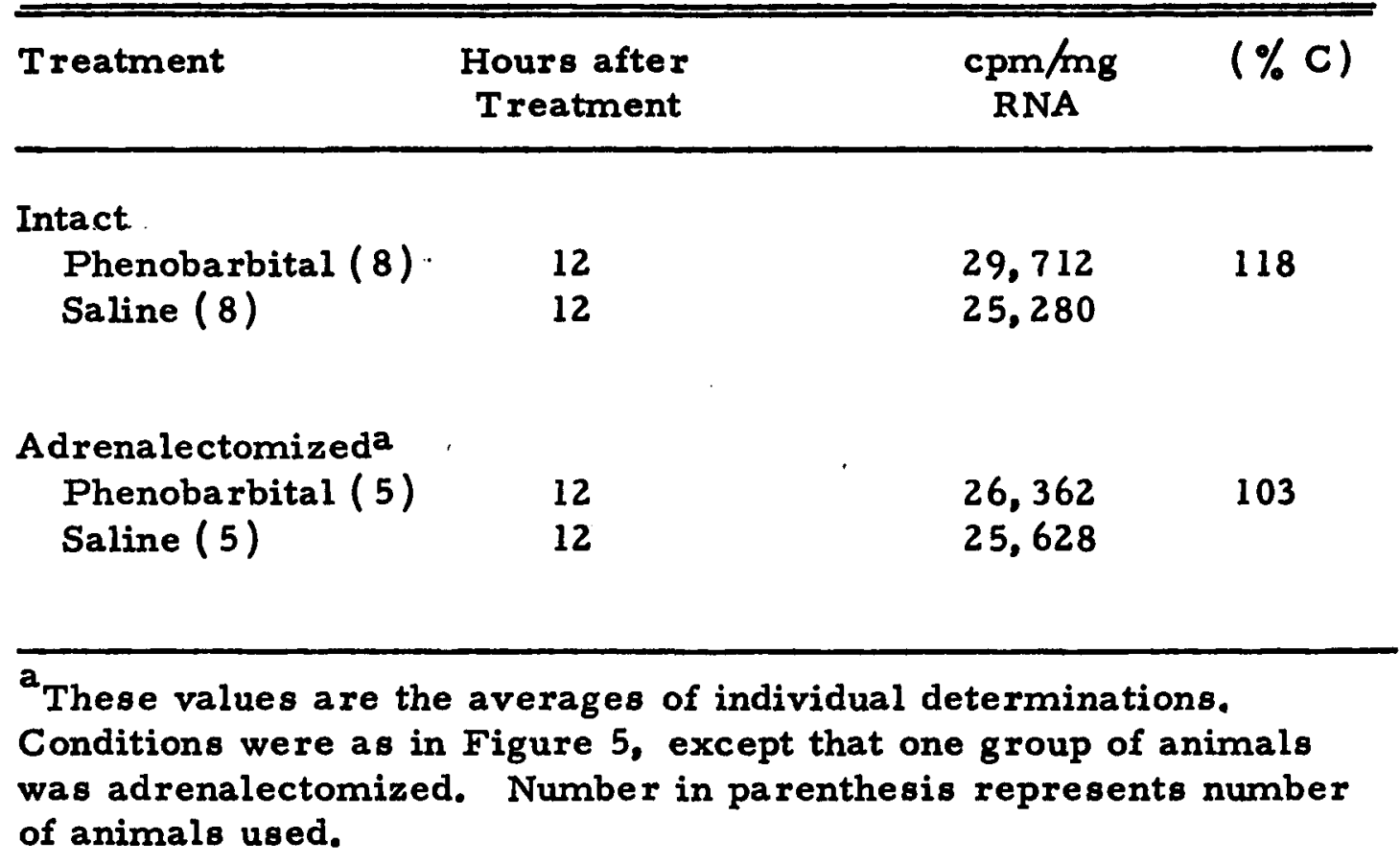


If the changes in microsomal RNA and ATP turnover are related through alterations in the rate of amino acid incorporation, it is of some importance to know the submicrosomal localization of the RNA in order to better describe its role in the hepatic response to phenobarbital. In order to determine the localization of the microsomal RNA, rats labeled for twelve hours with ${ }^{14} \mathrm{C}$-orotic acid ( $8 \mu \mathrm{C}$ ) and treated with saline or phenobarbital at zero time were used in the following experiments. Microsomes were prepared from one group of rats and then treated with $0.5 \%$ DOC, centrifuged, and the pellet $\left(R b_{2}\right)$ and the DOC supernatant separated (See Methods). Each of these fractions was extracted with phenol and the specific activity of the isolated RNA was determined. As can be seen from the data in Table 5, both fractions were well labeled at twelve hours. The DOC soluble RNA was more extensively labeled than the ribosomal RNA ( however, the ribosomal RNA represented over $80 \%$ of the $260 \mathrm{~m} \mu$ absorbing material). It is also evident that the specific activity of the ribosomal RNA was increased to a greater extent by phenobarbital treatment ( ribosomal RNA = $137 \%$ of control; DOC soluble RNA $=128 \%$ of control). The nature of the DOC soluble RNA is not clear; various authors have described it as being a 4 s RNA that is indigenous to microsomes (Gardner et al., 1968), as being a messenger RNA ( Pitot, 1969) or as being a mixture of ribosomal RNA and soluble RNA (Hoajgland et al., 1968). In any case, the extent of these experiments did not warrent any speculation on this problem.

Since ribosomes were preferentially labeled after phenobarbital treatment, an attempt was made to separate the ribosomes into free $\left(R b_{4}\right)$ and membrane bound $\left(R b_{3}\right)$ ribosomes by centrifugation of the post-mitochondrial supernatant on a discontinuous gradient (see Methods). The RNA from these fractions was isolated and its 
Table 5

Effect of Phenobarbital on Specific Activity of RNA in Microsomal Subfractions

\begin{tabular}{lllc}
\hline Subfraction & Treatment & $\begin{array}{c}\text { cpm/mg } \\
\text { RNA }\end{array}$ & (\% C) \\
\hline DOC soluble RNA & $\begin{array}{l}\text { phenobarbital (3) } \\
\text { saline (3) }\end{array}$ & $\begin{array}{l}27,609 \\
21,656\end{array}$ & 128 \\
mixed ribosomal & phenobarbital (4) & 17,487 & 137 \\
RNA ( Rb $)$ & saline (4) & 12,802 & \\
\hline
\end{tabular}

Intact rats were injected with $80 \mathrm{mg} / \mathrm{kg}$ phenobarbital (i. p) or saline and ${ }^{14} \mathrm{C}$ orotic acid ( $8 \mu \mathrm{c}$, i. v. ) and killed twelve hours later. Preparation and fractionation of the microsomes and determination of the specific activity of the RNA are described in Methods. Numbers in parenthesis represent the number of animals used; each value is the average of individual determinations. Individual determinations did not vary more than $15 \%$ from the mean. 
specific activity determined. It was found (Table 6) that the RNA from both the free and membrane bound ribosomes showed increased specific activity after treatment with phenobarbital. However, the specific activity of the membrane bound ribosomes was higher and was increased to a greater extent by phenobarbital (membrane bound RNA $=150 \%$ of control; free RNA $=118 \%$ of control ). These experiments indicate that phenobarbital treatment causes the appearance of higher specific activity RNA throughout the microsomal fraction of rat liver with a particularly high specific activity in the RNA of the membrane bound ribosomes.

Since the increase in the specific activity of the microsomal RNA is primàrily in RNA associated with ribosomes, and since cytoplasmic ribosomes are the principle sites of cellular protein synthesis in liver, it seemed likely that this increase and redistribution of RNA may result in increased protein synthesis. In an attempt to determine whether these alterations in microsomal RNA had any effect on amino acid incorporation, rats were treated with either phenobarbital or saline for twelve hours; five minutes before sacrifice a pulse of $5 \mu \mathrm{c}$ of ${ }^{14} \mathrm{C}$-leucine was administered by tail vein. Mixed ribosomes $\left(R b_{2}\right)$, free ribosomes $\left(R b_{4}\right)$ and membrane bound ribosomes $\left(R_{3}\right)$ were isolated as described in Methods. These fract: and for RNA content. This data was used to determine the in vivo amino acid incorporating activity of each of the classes of ribosomes. (cpm/mg RNA) and the effect of phenobarbital on the activity of each of these types of ribosomes. As can be seen in Table 7, membrane bound ribosomes incorporated radioactive leucine $60 \%$ better than free ribosomes irrespective of treatment and about equally as well as mixed ribosomes. This indicates that the bound ribosomes represent the most active fraction in amino acid incorporation in the 


\section{Table 6}

Effect of Phenobarbital on Specific Activity of RNA in Microsomal Subfractions

\begin{tabular}{|c|c|c|c|}
\hline Subfraction & Treatment & $\begin{array}{l}\mathrm{cpm} / \mathrm{mg} \\
\text { RNA }\end{array}$ & $(\% \mathrm{c})$ \\
\hline microsomal RNA & $\begin{array}{l}\text { phenobarbital (6) } \\
\text { saline }(6)\end{array}$ & $\begin{array}{l}19,274^{a} \\
15,718\end{array}$ & 123 \\
\hline $\begin{array}{c}\text { membrane bound } \\
\text { ribosomal RNA } \\
\qquad\left(R_{3} b_{3}\right)\end{array}$ & $\begin{array}{l}\text { phenobarbital }(7) \\
\text { saline }(7)\end{array}$ & $\begin{array}{l}26,665^{b} \\
17,786\end{array}$ & 150 \\
\hline $\begin{array}{l}\text { free ribosomal } \\
\text { RNA }\left(\mathrm{Rb}_{4}\right)\end{array}$ & $\begin{array}{l}\text { phenobarbital ( } 5) \\
\text { saline }(5)\end{array}$ & $\begin{array}{l}16,762^{c} \\
14,184\end{array}$ & 118 \\
\hline
\end{tabular}

Intact rats were injected with $80 \mathrm{mg} / \mathrm{kg}$ phenobarbital (i. p. ) or saline and ${ }^{14} \mathrm{C}$ orotic acid ( $8 \mu \mathrm{c}, i_{.}$. $)$and killed twelve hours later. Preparation and fractionation of the microsomes and determination of the specific activity of the RNA are described in Methods. Numbers in parenthesis represent the number of animals used; each value is the average of individual determinations.
a. $05>P>01$
b $\mathrm{P}<.01$
c $P>05$ 
Table 7

Incorporation of ${ }^{14} \mathrm{C}$ leucine into Ribosome Bound Polypeptides

\begin{tabular}{|c|c|c|c|}
\hline Subfraction & Treatment & $\begin{array}{c}\mathrm{cpm} / \mathrm{mg} \\
\text { RNA }\end{array}$ & $(\% \mathrm{C})$ \\
\hline $\begin{array}{l}\text { Mixed Ribosomal } \\
\quad\left(\mathrm{Rb}_{2}\right)\end{array}$ & $\begin{array}{l}\text { phenobarbital ( } 3 \text { ) } \\
\text { saline ( } 3 \text { ) }\end{array}$ & $\begin{array}{l}1,572 \\
1,303\end{array}$ & 121 \\
\hline $\begin{array}{l}\text { Free Ribosomal } \\
\qquad\left(\mathrm{Rb}_{4}\right)\end{array}$ & $\begin{array}{l}\text { phenobarbital ( } 3 \text { ) } \\
\text { saline }(3)\end{array}$ & $\begin{array}{r}1,015 \\
840\end{array}$ & 121 \\
\hline $\begin{array}{l}\text { Bound Ribosomal } \\
\left(\mathrm{Rb}_{3}\right)\end{array}$ & $\begin{array}{l}\text { phenobarbital ( } 3 \text { ) } \\
\text { saline ( } 3 \text { ) }\end{array}$ & $\begin{array}{l}1,693 \\
1,358\end{array}$ & 125 \\
\hline
\end{tabular}

Intact rats were injected with $80 \mathrm{mg} / \mathrm{kg}$ (i. p. ) with phenobarbital or saline and killed at twelve hours. Five minutes before sacrifice each rat was injected ( tail vein) with $5 \mu c{ }^{14} \mathrm{C}$ leucine. Microsomes and subfractions were prepared as described in Methods. Numbers in parenthesis represent number of animals used. Each value is the average of three individual determinations. . Individual determinations did not vary more that $12 \%$ from the mean. 
$\mathrm{Rb}_{2}$ pellet. It was also found that phenobarbital caused the ribosomes of all three classes to increase their rate of incorporation to the same extent (about $120 \%$ of control).

The experiments described in this section have indicated that an increased appearance of RNA in the microsomes is one of the early events in the hepatic response to phenobarbital. This RNA is primarily associated with membrane bound ribosomes, and results in a general increase in amino acid incorporation. Furthermore, the data suggest that the appearance of RNA in the membrane bound ribosomes may be causally related to the increased ATP turnover described earlier. These changes may be part of the sequence of events that leads to the proliferation and differentiation of the ER after phenobarbital treatment.

Influence of Phenobarbital on Hepatic Synthesis and Degradation of RNA

The experiments described in the preceeding section indicate that a high specific activity RNA appears in the microsomes and, particularly, the RER twelve hours after simultaneous administration of phenobarbital and orotic acid precursor. An explanation for these observations would be an increased incorporation of orotate into nuclear RNA after treatment with phenobarbital, and then, the consequent appearance of this RNA in the cytoplasm. Evidence from investigations by Stewart and Farber (1968) indicates that nuclear RNA labeled with orotic acid reaches eighty percent of its maximum specific activity within one hour after i. v. administration. This RNA is then presumably transported into the cytoplasm, and reaches maximum specific activity in the microsomes approximately fourteen hours after labeling. It was possible that phenobarbital had an immediate effect on the nuclear synthesis of RNA, and, the increased specific activity observed in the microsomes at later 
time periods was a consequence of the altered synthesis rate. Since nuclear RNA reaches its maximum specific activity quite rápidly after intravenous injection of radioactive orotate, any influence on the rate of nuclear synthesis would have to occur within an hour after the simultaneous administration of drug and precursor to be detected in the experiments described in figure 5, Table 5. and Table 6.

In order to investigate the possibility that RNA was being synthesized at a more rapid rate after treatment with phenobarbital, rats were treated at zero time with phenobarbital and injected intravenously with orotic acid at the times indicated in figure 6 , then killed twenty minutes later. 'A twenty minute pulse time was selected because it has been shown that in untreated rats (Stewart and Farber, 1968: Hiatt, 1962) very little RNA has left the nucleus within this time period. This measurement should minimize any influence that transport of RNA from the nucleus may have on the synthesis rate and make it possible to estimate the synthesis of nuclear RNA by determining the specific activity of cellular RNA. The data described in figure 6 represent the specific activity of RNA isolated from liver homogenate and show that phenobarbital had no influence on the synthesis of RNA immediately or one hour after drug treatment; however, three hours after treatment the rate of orotate incorporation was increased by about sixty percent. The data in figure 6 suggest that cytoplasmic distribution of RNA ( table 5, table 6) is not the result of increased synthesis of RNA. However, figure 6 also provides evidence that the synthesis of RNA may play a role in the response of the liver to phenobarbital (Zemp, 1968).

It will be noted in figure 6 that the rate of orotic acid incorporation in saline treated rats increased progressively from the zero time to three hours. This increase may be a reflection of the influence of intraperitoneal injection (possibly through a stress) on the 
Figure 6

Early Influence of Phenobarbital on RNA Synthesis

Rats were injected with phenobarbital ( $80 \mathrm{mg} / \mathrm{kg}$, i. p.) at zero time and then injected with $4 \mu \mathrm{c}$ of radioactive orotic acid (i.v.) at the indicated times. Twenty minutes later the animals were killed and the specific activity of the RNA extracted from the homogenized liver was determined (Methods). Each point represents the average of from three to five rats. 


\section{EARLY INFLUENCE OF PHENOBARBITAL \\ ON RNA SYNTHESIS}

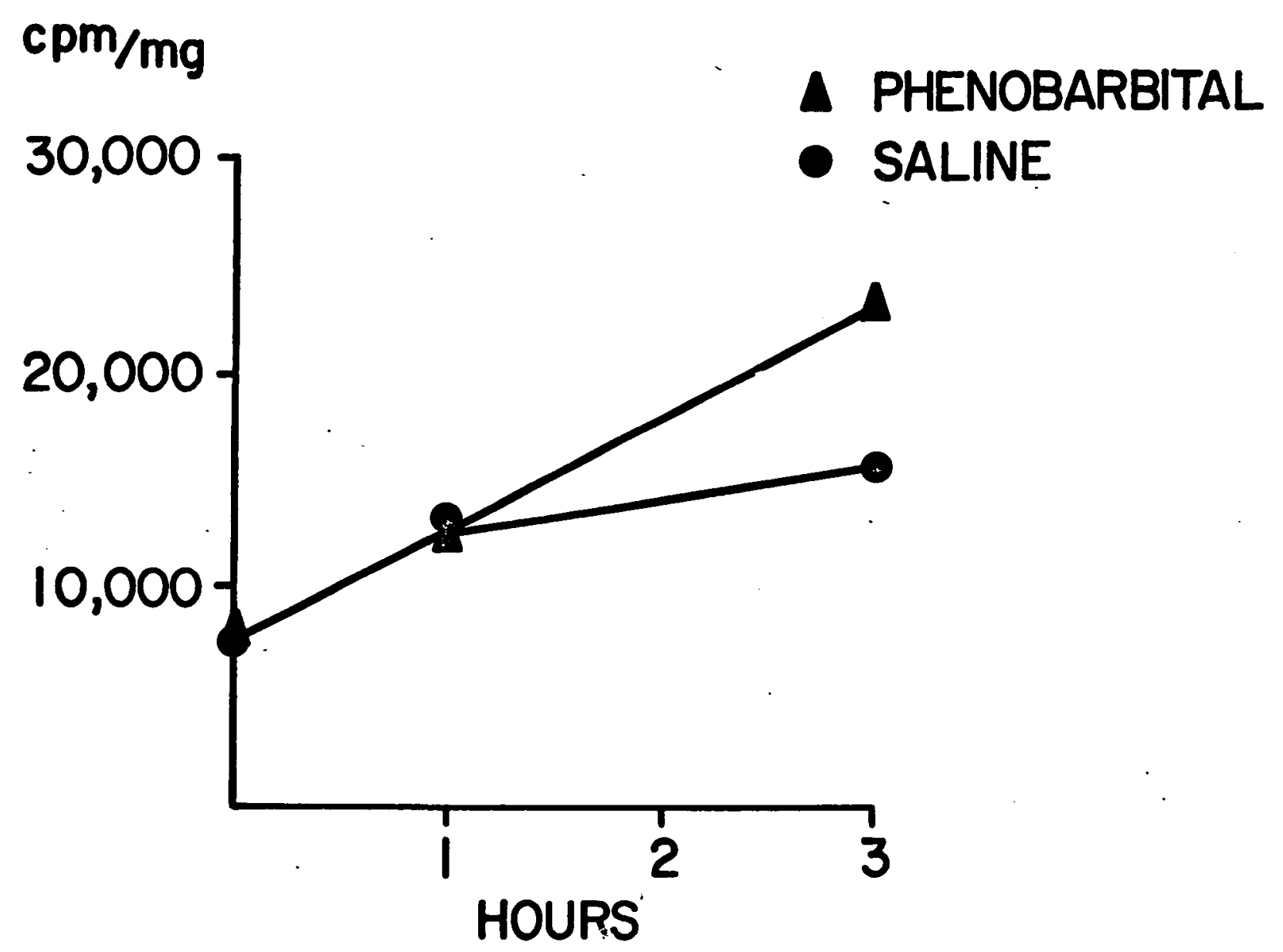


rate of RNA synthesis, although other possible explanations may exist.

Another explanation for the increased specific activity of membrane bound ribosomes might be a decrease in the degradation of these ribosomes. This possibility is unlikely since Hirsch et al (1966) have estimated the half time of degradation of hepatic ribosomal RNA at approximately five days; it is difficult to imagine that a decrease in the degradation of ribosomal RNA caused by phenobarbital would produce a measurable effect within twelve hours. However, since much recent evidence has indicated that phenobarbital treatment alters the degradation rate of several microsomal proteins (Kuriyama et al. , 1969; Shuster et al., 1968; Jick et a1., 1968), and since a decrease in the degradation rate of microsomal RNA may contribute to the increased specific activity seen in figure 5 and Table 6, experiments were conducted to investigate the influence of phenobarbital treatment on the disappearance of radioactivity from microsomal RNA.

In order to estimate the influence of phenobarbital on the degradation rate of microsomal RNA, rats were injected with $4 \mu \mathrm{c}$ of ${ }^{14} \mathrm{C}$-orotic acid at zero time. Eight hours later the rats were injected with either phenobarbital or saline and this injection was repeated every twelve hours (Shuster et al., 1968) until the rats were killed. Each day for four days, three rats in each group were killed and microsomes were prepared. The microsomes were subjected to a todified Schmidt-Thannhauser extraction and radioactivity in the RNA fraction was estimated and expressed in figure 7 as counts per minute per liver.

As can be seen in this figure, rats treated with phenobarbital apparently retain radioactive RNA somewhat longer than their saline treated controls. Approximate half lives determined by 
Figure 7

Effect of Phenobarbital on the Degradation of Microsomal RNA

Rats were injected at zero time with $4 \mu \mathrm{c}$ of orotic acid (i. v.), and then, at the times indicated by the arrows, the animals were injected with either phenobarbital $(80 \mathrm{mg} / \mathrm{kg}$ ) or saline by the intraperitoneal route. Animals were killed at the indicated times and the radioactivity of the microsomal fraction was determined and expressed as radioactivity in RNA per liver. Each point is the average of three individual determinations. 
EFFECT OF PHENOBARBITAL ON DEGRADATION

OF MICROSOMAL RNA

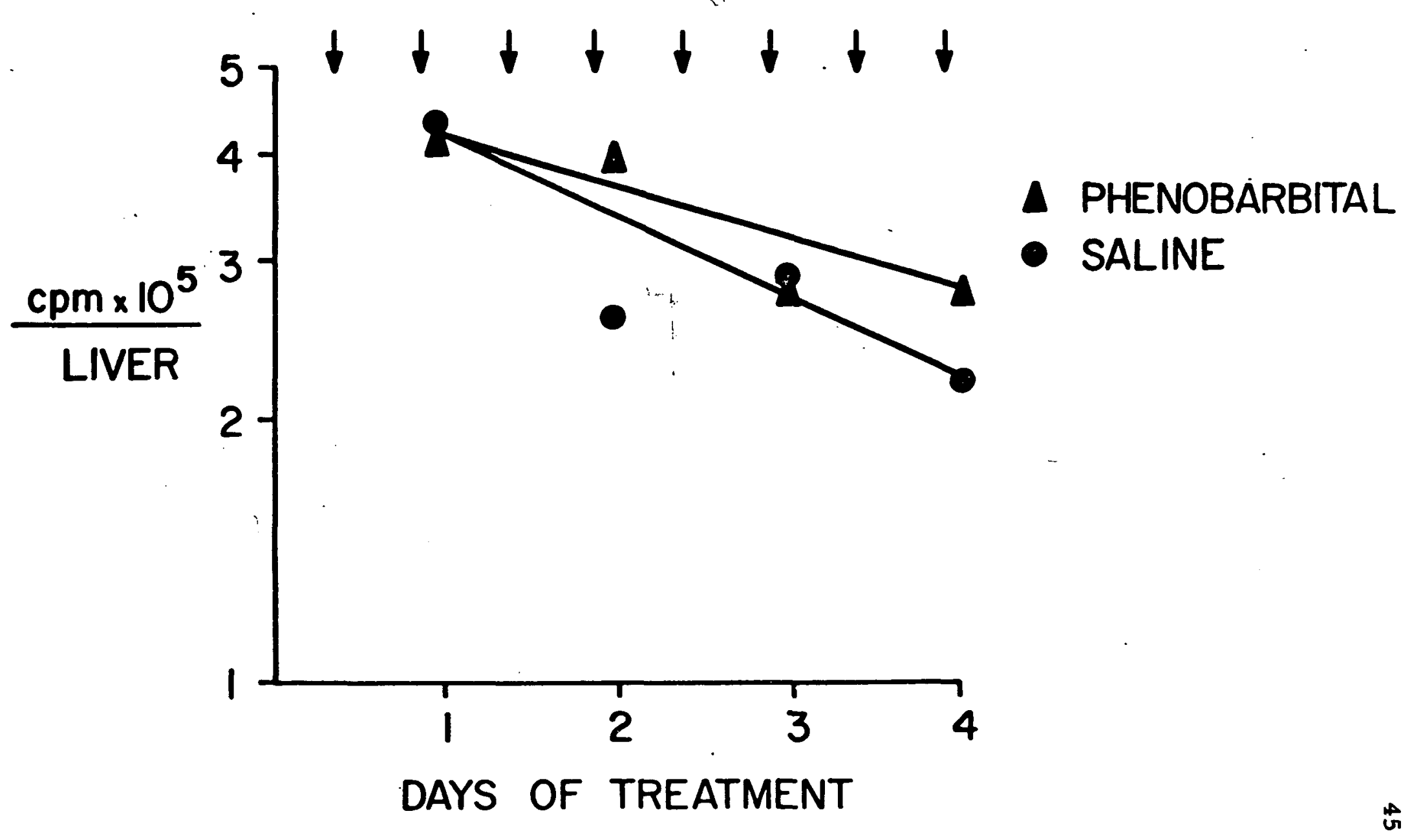


extension of the lines plotted in figure 7 are four days for salinetreated rats and five and one-half days for phenobarbital-treated rats. This degradation rate is probably accurate since Hirsch et al ( 1966 ) have demonstrated that radioactive orotic acid is not readily re-utilized for RNA synthesis; however, the possibility exists that phenobarbital may stimulate this type of reincorporation. For this reason, the rate of degradation of RNA in phenobarbital treated rats estimated in figure 7 must be regarded as a minimal rate. It is apparent that the rate of degradation is not sufficiently slowed to account for the increased specific activity seen in figure 4 (i. e., it would take several days to increase the radioactivity of the phenobarbital treated rats $20 \%$ above control).

In this section some aspects of the influence of phenobarbital on the nuclear synthesis and cytoplasmic degradation of RNA were measured. Although both of these parameters may be affected by the barbiturate, neither of these effects account for the distribution of cytoplasmic RNA described earlier.

Effect of Phenobarbital Treatment on In Vitro Binding of Polysomal RNA

It is evident from the preceeding sections that phenobarbital treatment causes a preferential increase in the specific activity of membrane bound ribosomes which cannot be accounted for by alterations in the synthesis or degradation of RNA. Another effect of phenobarbital that might increase this specific activity would be an increase in the number of sites on the RER to bind ribosomes. In order to test these possibilities, the RER was isolated from rats that had been treated with either phenobarbital or saline for twelve hours and then it was stripped of its ribosomes (See Methods). These membranes were combined as described by Suss et al. (1966)

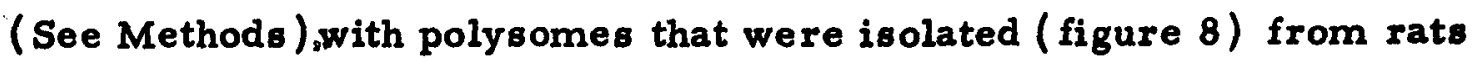




\section{Figure 8}

\section{Rat Liver Polysomal Profile}

The $R b_{1}$ fraction was isolated as described in Methods, from the livers of 3 pooled rats that had been treated with either $80 \mathrm{mg} / \mathrm{kg}$ phenobarbital or an equal volume of saline and $8 \mu \mathrm{c}$ of orotic acid $\left({ }^{14} \mathrm{C}\right) .0 .75 \mathrm{ml}$ of the $\mathrm{Rb}_{1}$ fraction was layed over $\mathrm{a}$ linear sucrose gradient $(26 \mathrm{ml} ; 10-40 \%)$ containing $0.005 \mathrm{M}$ $\mathrm{MgCl}_{2}$ and centrifuged in a SW 25.1 rotor in a Spinco L2 centrifuge at 20,000 rpm for two hours. Approximately $1 \mathrm{ml}$ fraction were collected by piercing the bottom of the tube, and radioactivity was determined by liquid scintillation; $260 \mathrm{m \mu}$ absorbance was determined in a Beckman DU. 
RAT LIVER POLYSOMES

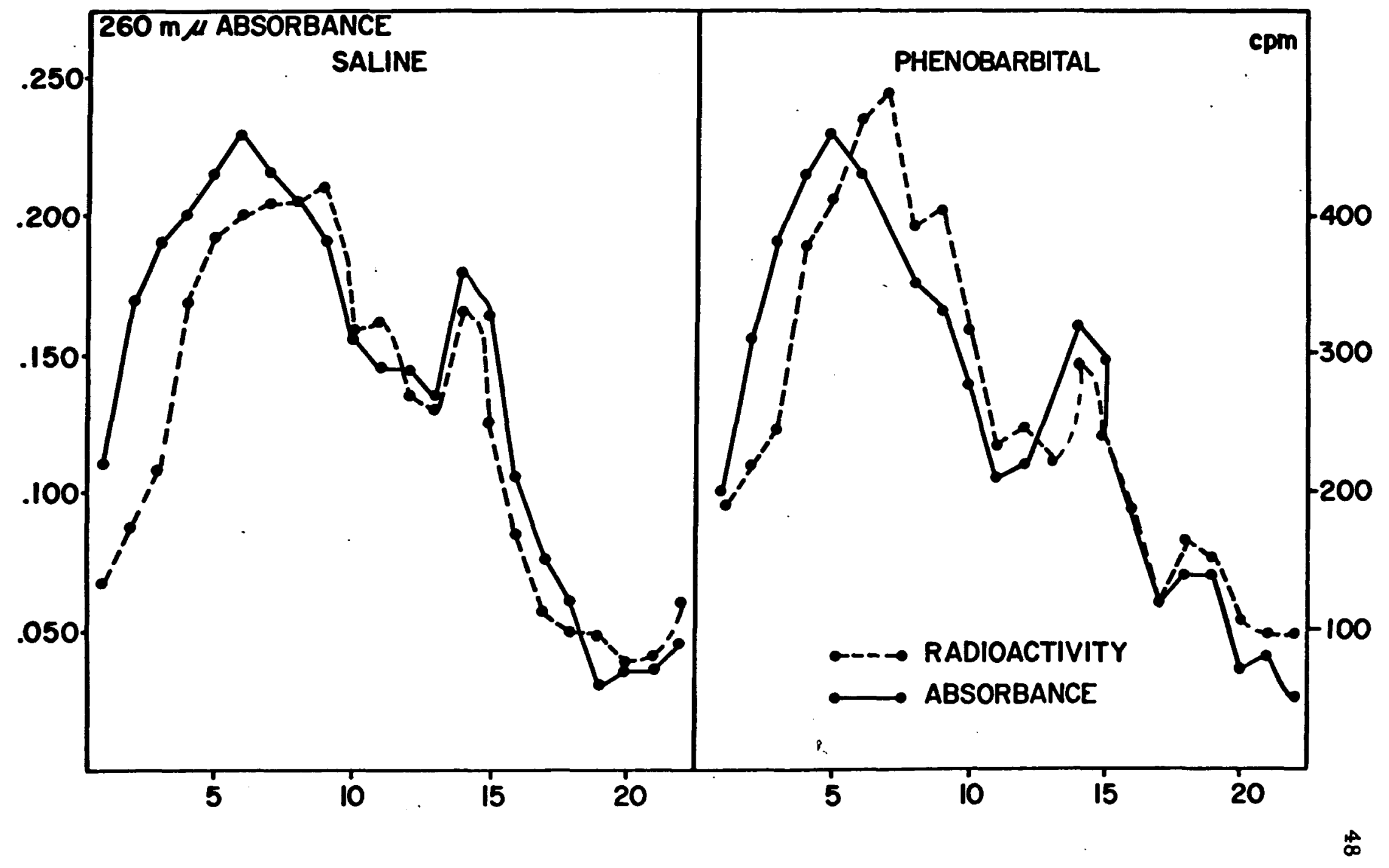


that were similarly treated and labeled with ${ }^{14} \mathrm{C}$-orotate for twelve hours. The results of these recombination experiments are in Table 8.

In experiment I of Table 8, approximately $100 \mathrm{\mu g}$ polysomal RNA was combined with $640 \mu g$ of stripped RER. In this experiment, the polysomes were bound to approximately the same extent when radioactivity per mg membrane was considered. When the mg RNA bound per mg membrane protein were calculated, it appeared that phenobarbital polysomes were bound to phenobarbital membrane to a lesser extent than in the control experiment ( $73 \%$ of control). In these experiments $30-40 \%$ of the polysomal RNA was bound to the membranes. In experiment II, approximately $850 \mathrm{~kg}$ of polysomal RNA was incubated with $640 \mathrm{\mu g}$ of membrane and again phenobarbital treatment had no effect on the extent of binding of the RNA to the membrane. In these experiments $17-19 \%$ of the polysomal RNA was bound to membranes. The above experiments suggest phenobarbital does not alter either the affinity of the membrane for polysomal RNA or (as the binding approached saturation) the number of sites available for binding.

The possibility existed that the binding of polysomes to the stripped membranes was artifactual. That is, the polyribosomes may have been trapped within the vesicles of the membrane instead of bound on the membrane surface. This possibility was unlikely since Suss et al ( 1966 ) have shown that polyribosomes bind to a greater extent to the RER of normal liver than to SER from the same animal. However, the possibility of artifactual inclusion of ribosomes was investigated by electron microscopy ( kindly performed by Dr. N. Baba . Department of Pathology, The Ohio State University). Samples (from experiment II) were taken of saline membranes before recombination (figure 9 ) aline membrane recombined with saline 
Table 8

Effect of Phenobarbital Treatment on Binding of Polysomes to RER

\begin{tabular}{|c|c|c|c|c|}
\hline & $\begin{array}{c}\text { Membrane } \\
\text { (mg protein) }\end{array}$ & $\begin{array}{l}\text { Polysomes } \\
\text { (mg RNA) }\end{array}$ & $\begin{array}{l}\text { cpm in RNA } \\
\text { mg protein }\end{array}$ & $\begin{array}{l}\text { mg RN } \\
\text { mg prote }\end{array}$ \\
\hline \multicolumn{5}{|l|}{ Experiment I } \\
\hline phenobarbital & 0.64 & 0.095 & $\begin{array}{l}1009 \\
1063\end{array}$ & 0.032 \\
\hline saline & 0.64 & 0.101 & $\begin{array}{l}1109 \\
1063\end{array}$ & 0.044 \\
\hline \multicolumn{5}{|l|}{ Experiment II } \\
\hline phenobarbital & 0.64 & 0.833 & $\begin{array}{l}4867 \\
5875 \\
5384\end{array}$ & 0.159 \\
\hline saline & 0.64 & 0.875 & $\begin{array}{l}5760 \\
5438 \\
2871\end{array}$ & 0.150 \\
\hline
\end{tabular}

Both RER and polysomes were isolated from rats that had been treated for twelve hours with phenobarbital or saline as described. The RER was stripped of ribosomes according to the method of Suss, 1966. Polysomes were isolated by the method of Webb, 1964, from rats that had bein given $8.0 \mu \mathrm{c}$ of ${ }^{14} \mathrm{C}$ orotic acid $12 \mathrm{hrs}$. before sacrifice. Membrane and polysomes from similarly treated rats (i. e., membrane from rats treated with phenobarbital was incubated with radioactive polysomes from a phenobarbital treated rat) were recombined as described in Methods. Protein was determined by Lowrys method (1951) and RNA by $260 \mathrm{m \mu}$ absorbance. Mg RNA combined with $\mathrm{mg}$ membrane was calculated from the specific activity of the isolated polysomes and the average of the specific activities of the recombined RNA membrane for each treatment. Individual determinations are expressed as cpm in RNA/mg protein. Stripped RER for each treatment was isolated from the pooled livers of six rats. Polysomes were isolated from the pooled livers of three rats for each treatment. 
Figure 9

"Stripped" RER

Electron micrograph " of RER isolated from livers of six pooled rats that had been treated with saline twelve hours previously. These membranes were "stripped" as described in Methods.<smiles>[CH]</smiles> 


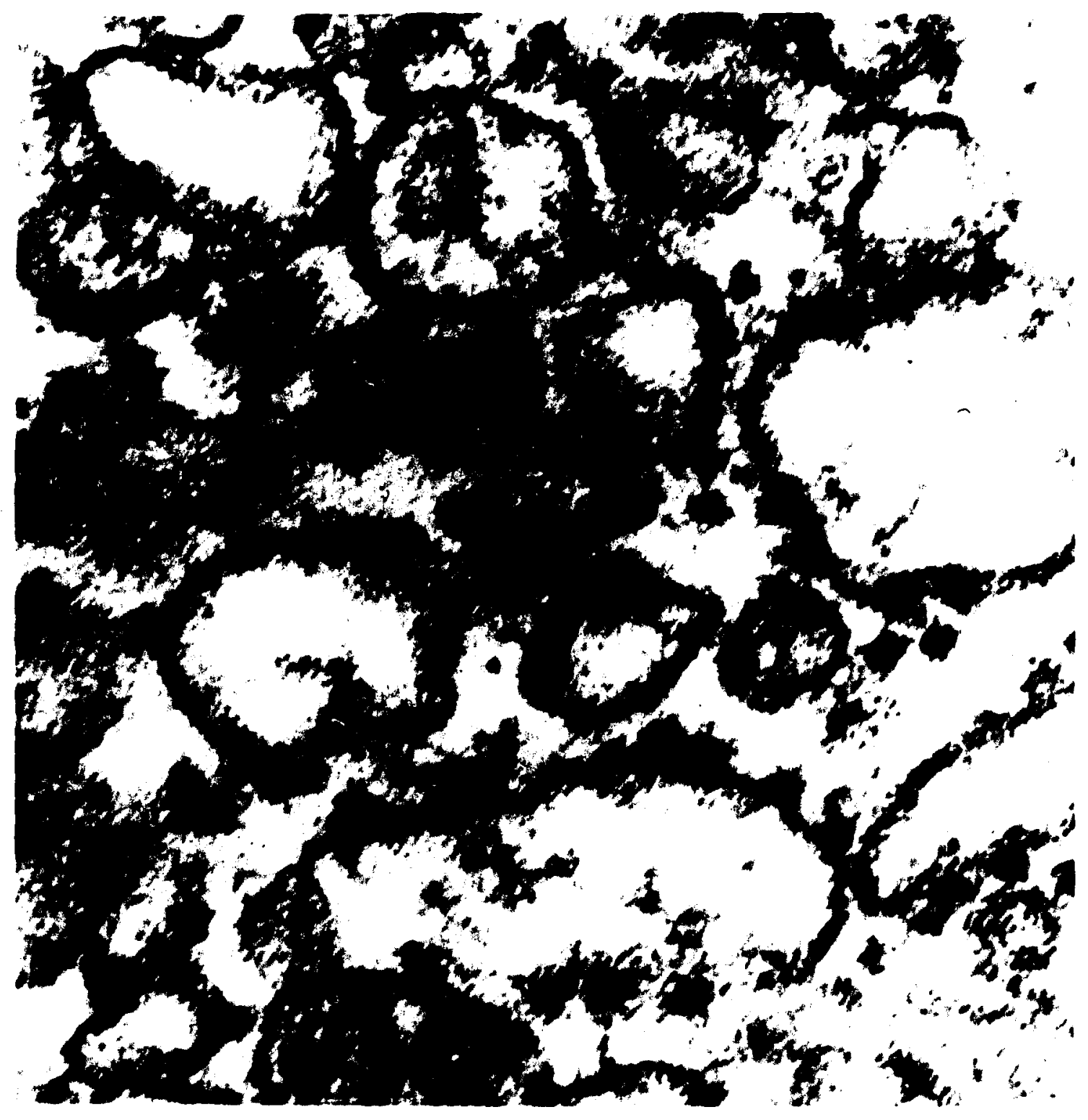




\title{
Figure 10
}

Reconstituted RER from Saline Treated Rats

\begin{abstract}
Electron micrograph of "stripped" reconstituted RER isolated from livers of six pooled rats that had been treated with saline twelve hours previously. Polysomes were isolated from pooled livers of three similarly treated rats that had also been labeled with radioactive orotic acid and recombined with the membranes.
\end{abstract}





\section{Figure 11}

Reconstituted RER from Phenobarbital Treated Rats

Electron micrograph of "stripped" reconstituted RER isolated from livers of six pooled rats that had been treated with phenobarbital twelve hours previously. Polysomes were isolated from pooled livers of three similarly treated rats that had also been labeled with radioactive orotic acid and recombined with the membranes. 


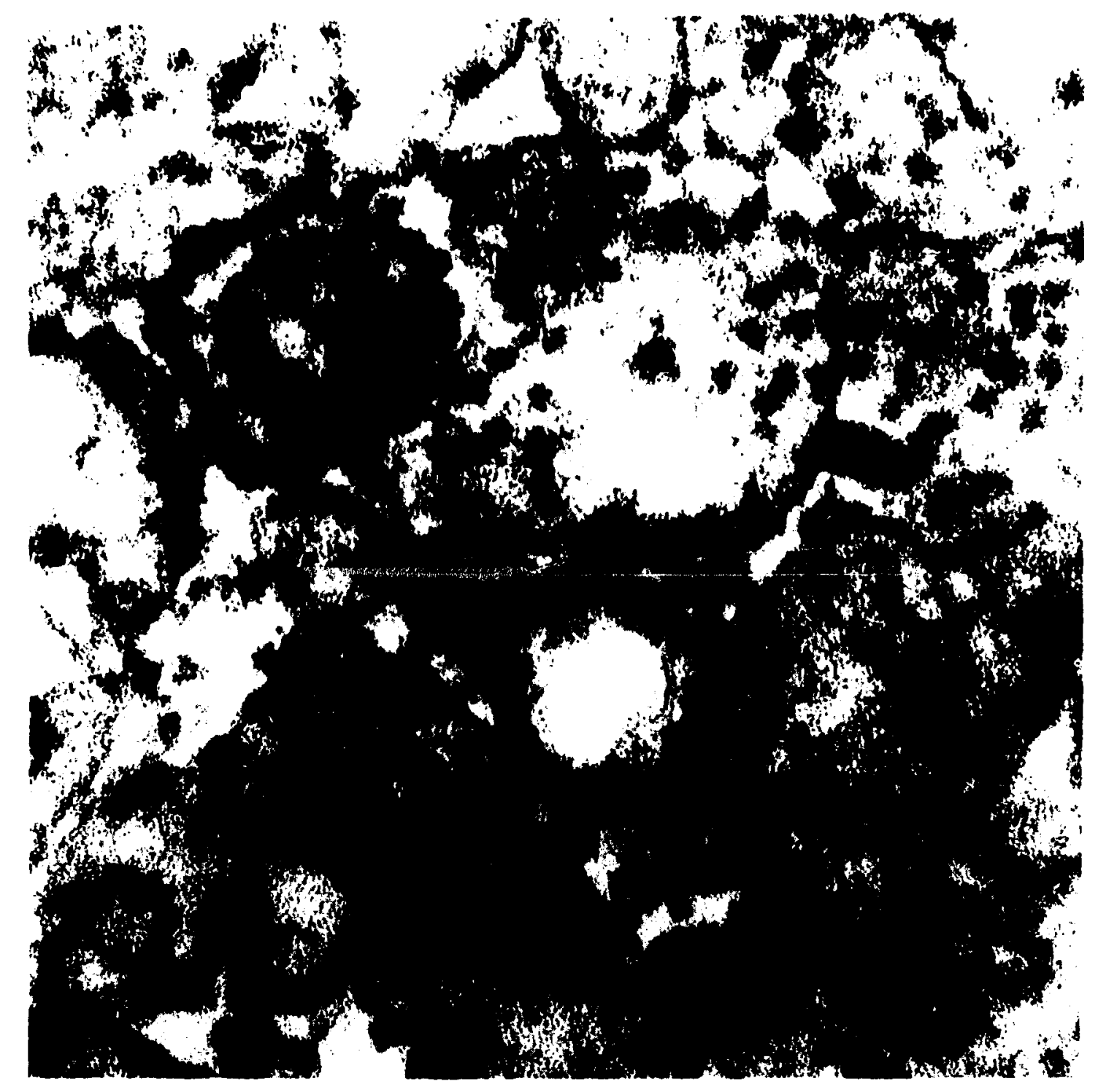


polysomes (figure 10) and phenobarbital membrane recombined with phenobarbital polysomes (figure 11) and representative electron micrographs are presented. In the uncombined membrane there are still some ribosomes present but considerably less than in the combined preparations. Furthermore the majority of the ribosomes are located on the membrane and not trapped within. The electron micrographs eliminate the possibility of artifactual binding and visually confirm the data of Table 8; however, it is still possible that the in vitro binding of ribosomes may not reflect other in vivo influences on the distribution of RNA to the membranes of the RER.

The Influence of Cycloheximide and Phenobarbital on the Appearance of Ribosomes in the Cytoplasm

Several recent reports have indicated that proteins associated with RNA may be important in the transport of RNA out of the nucleus ( Parsons et al., 1968) or in the assembly of polysomes in the cytoplasm (Henshaw, 1968). Furthermore, it has been demonstrated that in partially hepatectomized rats (another type of experimental liver growth), the expected increase in cytoplasmic ribosomes is abolished ( returns to control level) after a fifteen minute pretreatment with $50 \mathrm{mg} / \mathrm{kg}$ cycloheximide (Chaudhuri et al., 1968). The above cited literature suggests that several aspects of RNA metabolism may be sensitive to translational influences. In light of the minimal influence of phenobarbital on either the nuclear synthesis or microsomal degradation rates of RNA and the apparent lack of effect of the drug on the in vitro binding of polysomes to RER it was considered possible that the barbiturate might exert some more subtle effect on the synthesis of proteins related to the movement or disposition of RNA in the cytoplasm. 
In order to test the possibility that the distribution of radioactive RNA to the RER caused by phenobarbital was related to protein synthesis, the following experiment was performed. Rats were treated simultaneously with phenobarbital or saline and radioactive orotate as described in Table 6; however, thirty minutes before labeling both groups of rats were given a single i. p. injection of $500 \mu \mathrm{g} / \mathrm{kg}$ cycloheximide. Cycloheximide is a potent inhibitor of protein synthesis; the dose used in this experiment has been shown to inhibit hepatic protein synthesis by $80 \%$ within a hàlf an hour ( Yeh et al., 1969). This level of inhibition is maintained for several hours and then gradually diminishes until, at twelve hours posttreatment, hepatic protein synthesis is about $60 \%$ of control. Aside from its rapid and profound action on protein synthesis, cycloheximide has several other characteristics that are important to this experiment. It has been shown by several investigators (Chaudhuri .et al., 1968; Ennis, 1966; Rizzo et al., 1969) that in doses ranging from $1 \mathrm{mg} / \mathrm{kg}$ to $50 \mathrm{mg} / \mathrm{kg}$, cycloheximide has little to no effect on the rate of incorporation of precursor orotate into RNA in control rats. Furthermore, it has been shown by Wettstein et al ( 1964 ) and Rizzo et al (1969) that both in vitro and in vivo, cycloheximide stabilizes polysomes so that larger aggregates are produced. These data can be taken to indicate that cycloheximide, under normal conditions, neither interferes with nuclear synthesis of RNA nor accelerates the microsomal destruction of polysomal RNA.

Twelve hours after treatment with phenobarbital or saline and radioactive precursor, the cycloheximide treated rats were killed, and the specific activities of the membrane bound and free ribosomes were determined. These data and similar data obtained from rats not treated with cycloheximide (Table 6) are compared in Table 9. It is apparant that cycloheximide treatment lowered the specific 


\section{Table 9}

The Influence of Cycloheximide Pretreatment on the 6 Specific Activity of Cytoplasmic Ribosomes

Ribsosmal Fraction
Membrane

bound $\left(\mathrm{Rb}_{3}\right)$ phenobarbital ( 7 )
phenobarbital+cyclo saline ( 7 )

saline+cycloheximide (6)

Treatment $\mathrm{cpm} / \mathrm{mg} \quad(\% \mathrm{C})$

RNA

Free $\left(R b_{4}\right)$

phenobarbital ( 5 )

16,762

phenobarbitaltcycloheximide (6) $\quad 3,075^{\mathrm{a}}$

saline (5)

saline+cycloheximide (6)

14,184

$3,051^{a}$

22

59

22

Intact rats were injected with $80 \mathrm{mg} / \mathrm{kg}$ phenobarbital (i. p. ) or saline and ${ }^{14} \mathrm{C}$ orotic acid $(80 \mu \mathrm{c}, \mathrm{i} . \mathrm{v}$. ) and killed twelve hours later. In the indicated instances the injection of precursor orotate was preceeded by thirty minutes with an injection of $0.5 \mathrm{mg} / \mathrm{kg}$ cycloheximide (i. p. ). Preparation and fractionation of the microsomes and determination of specific activity of RNA are described in Methods. Numbers in parenthesis represent number of animals used; each value is the average of individual determinations.

a different from corresponding animals not treated with cycloheximide to $P<.01$

$b_{\text {different from animals treated with saline and cycloheximide to }}$ $.05>$ P. $>01$. 
activity of both free and bound ribosomes irrespective of whether the animal was treated with phenobarbital or saline. This observation indicates that the appearance of ribosomes in the cytoplasm. is dependent on protein synthesis. The specific activities of free ribosomes from both phenobarbital and saline treated rats were affected to the same extent by cycloheximide pretreatment. The absolute specific activities were the same after cycloheximide, and the decrease in specific activity (as compared to control rats not treated with cycloheximide) was quite similar. Although the specific activity of membrane bound ribosomes after cycloheximide was lowered in both barbiturate and saline treated animals ( relative to control animals not treated with cycloheximide), rats treated with phenobarbital showed a larger relative decrease (decreased approximately $80 \%$ ) than did saline treated rats (decreased $40 \%$ ). The larger relative decrease in specific activity of bound ribosomes exhibited by barbiturate treated rats is partly due to the fact that the specific activity of bound ribosomes in these rats not treated with cycloheximide is higher than the corresponding fraction from saline rats; however, it is noteworthy that the absolute specific activity of bound ribosomes from rats treated with phenobarbital and cycloheximide is $45 \%$ lowe $r$ than in rats treated with saline and cycloheximide.

The data in Table 9 suggest that the appearance of ribosome associated RNA in the cytoplasm is dependent on ongoing protein synthesis. Observations with microsomal RNA similar to those in Table 9 have been made by Stewart et al. (1968) using ethionine as an inhibitor of protein synthesis. It is particularly relevant that the membrane bound ribosomes in control animals (saline treated) are more resistant to interuption of protein synthesis than free ribosomes from these animals; while in phenobarbital treated animals, 
the membrane bound ribosomes are dramatically affected by cycloheximide treatment. These data may suggest that phenobarbital exerts its effect on bound ribosomes through a translational control mechanism. 


\section{DISCUSSION}

Phenobarbital is one of a number of agents that increases the level of hepatic microsomal enzymes (Conney, 1967). However, phenobarbital also has a profound anabolic effect on liver; both liver weight and hepatic SER are increased by several daily treatments with the barbiturate. This type of response has been reported by many investigators and has been demonstrated in figure 2 of this report. Although the various enzymatic and anabolic changes caused by phenobarbital have been extensively investigated in animals treated with the drug for several days, relatively few studies have been concerned with the effects of a single injection of the barbiturate. The present investigations are concerned with events that occur within the first twenty four hours after a single drug treatment that may lead to hepatic growth and SER proliferation. These studies are based on the assumption that liver growth is one of the primary actions of phenobarbital and that by examining the chronology of events that may lead to liver growth it is possible to better describe the initial action of the drug.

The effect of phenobarbital on the levels of hepatic adenine nucleotides and ATP turnover was investigated on the assumption that liver growth would be a major energy requiring process and that initiation of this process would be reflected in alterations in adenine nucleotide metabolism. Initially the concentrations of the three nucleotides, ATP, ADP and AMP, were measured over the first twelve hours of phenobarbital treatment. The data in Table 1 indicate that the treated rats did not show appreciable differences 
in the concentration of any of the nucleotides. These results were not entirely unexpected since other investigators (Ove et al., 1967) have shown that events which alter liver metabolism such as partial hepatectomy and acute stress have relatively little effect on the steady state concentrations of the adenine nucleotides. Although the adenine nucleotide levels were not changed by treatment with phenobarbital, it was still possible that the nucleotides were being used at a greater rate after drug administration, but that they were being rapidly restored to their steady state concentrations by increased phosphorylation.

In order to investigate this possibility, the level of ATP turnover was measured by using short pulses of radioactive phosphate and measuring its incorporation into ATP. This measurement has been shown to be a reliable estimate of the synthesis of ATP in face of increased utilization (Ove et al., 1967). The turnover of ATP at several points up to twenty four hours after drug treatment is shown in figure 4. There are apparently two time intervals in which ATP turnover is affected by the treatment of the animals. First, there appears to be an early peak in ATP turnover that occurs at six hours and has disappeared by ten hours. This peak occurs in both drug and saline injected animals; although, it is more prominent in the saline-treated rats. These early peaks are abolished by adrenalectomy (Table 2 ); however, in intact rats, at the six hour point there is no measurable change in plasma corticosterone ( Table 3). Over a similar time course, Ove et al. (1968) have noted a peak in ATP turnover in the same time period after injection of Celite. This peak was similar to the early peak in figure 4 since it was abolished by adrenalectomy, but could not be produced by a variety of synthetic corticoids. As well as the early peak in ATP turnover, there is a later and more pronounced peak 
that only occurs in rats that have been treated with phenobarbital. This second increase in ATP turnover was first observed at fourteen hours and remained throughout the twenty four hour period; although, it had begun to gradually approach the control level by twenty four hours. The second peak like the first, was abolished by adrenalectomy ( Table 2 ) and in intact rats, was not associated with an alteration in plasma corticosterone ( Table 3 ).

There are several possible interpretations of the data concerning phenobarbital's effect on adenine nucleotide turnover. One interpretation would be that since both early and late peaks are abolished by adrenalectomy, the effect on ATP turnover is mediated by corticoids and that phenobarbital may have some action on the adrenal gland directly or through some higher center. However, this prospect is made unlikely by the fact that the levels of plasma corticoids are not elevated at either of the times when ATP turnover is maximal. Furthermore, Ove et al. (1968) were unable to produce an increased ATP turnover with several synthetic corticoids in experiments very similar to those described above. Another explanation would be that both early and late peaks are the result of release of catecholamines from the adrenal gland. Phenobarbital may have an adrenal catecholamine releasing effect that is delayed and produces the second increase in ATP turnover. The first peak in ATP turnover (present in both saline and phenobarbital treated rats) may be due to the release of catecholamines as the result of the stress of intraperitoneal injection. These data would explain the data concerning plasma corticoids and adrenalectomy ( Tables 2, 3). A third interpretation, which is supported by subsequent data, is that the first peak in ATP turnover is the result of a catecholamine mediated stress as a consequence of intraperitoneal injection and that the second and later peak is the result of a 
direct, but adrenal dependent effect of phenobarbital on the liver. This interpretation is consistent with results obtained by other investigators. It has been recently shown by Orrenius et al. $(1968 \mathrm{~b})$ that adrenalectomy and castration profoundly reduce the hepatic response to phenobarbital. The activities of three proteins, $P-450, T P N H$ cytochrome $c$ reductase and aminopyrine demethylase (which are normally elevated several fold by phenobarbital treatment) are virtually unchanged in drug treated adrenalectomized castrated rats. In these experiments, the activities of all three proteins could be elevated in similarly treated rats given $80 \mathrm{mg} / \mathrm{kg}$ phenobarbital and $80 \mathrm{mg} / \mathrm{kg}$ testrosterone propionate. Wilson et al. (1967) have shown that the activity of the DNA dependent RNA polymerase (in the presence of ammonium sulfate), which is normally elevated by phenobarbital, is unaffected in hypophysectomized rats; altksugh, the polymerase is still responsive to phenobarbital in adrenalectomized rats. These data indicate that the response of the liver to phenobarbital is quite sensitive to alterations in endocrine balance. Therefore, it would not be surprising that some of the events that are directly attributable to a hepatic action of the barbiturate might be sensitive to adrenalectomy.

Although the data concerning ATP turnover (figure 4, Table 2) collected in this report do not allow one to distinguish between the last two above mentioned interpretations, I have selected the last alternative (an ea rly peak as a result of an adrenal mediated response to intraperitoneal injection of saline or phenobarbital and a later peak as the result of a direct but adrenalcortical-sensitive hepatic response to phenobarbital). Evidence favoring the latter interpretation would be: (1) there is no available evidence that phenobarbital has an adrenal catecholamine releasing effect, (2) the latter interpretation is the most consistent with other data in this report, and ( 3 ) previously cited literature indicates that at least 
some aspects of the hepatic response to phenobarbital are quite sensitive to alterations in endocrine status.

If the later peak in ATP turnover is, indeed, due to a direct action of phenobarbital on hepatic metabolism, it is possible that this increase in energy utilization is related to the anabolic effect of the barbiturate. Since microsomal protein synthesis is one of the prominent events in the liver response to phenobarbital (Kato et al., 1965) and since recent investigations have indicated that protein synthesis has increased in the microsomes within twenty four hours (Kuriyama et al., 1969), it seemed likely that the ATP turnover might be related to this process. An event that might lead to increased protein synthesis would be an increase in RNA that was active in amino acid incorporation. In order to investigate this possibility the appearance of microsomal RNA in the cytoplasm was investigated.

In these experiments, radioactive orotic acid was given at zero time simultaneously with a $80 \mathrm{mg} / \mathrm{kg}$ dose of phenobarbital, then animals were killed at various times afterward and the specific activity of the microsomal RNA was determined. This type of measurement indicates the influence of phenobarbital on the movement of RNA (synthesized at zero time) into the microsomes. It can be seen in figure 5 that phenobarbital treated rats showed a modest increase in specific activity at twelve and eighteen hours and that this increase has returned to control levels by twenty four hours after drug treatment. Although the increase in specific activity is not dramatic (Table 6) it is well correlated in time with the fourteen hour peak in ATP turnover. Furthermore, as the specific activity of the microsomal RNA approaches control, the peak in ATP turnover decreases towards control. The correlation in time of these two events suggested that they might be related. 
Since the ATP turnover is sensitive to adrenalectomy, if the appearance of RNA in the microsomes is related to the ATP turnover, it would be expected that adrenalectomy would also abolish the increased specific activity of the microsomal RNA. In order to determine whether the appearance of microsomal RNA was adrenal sensitive, a group of rats were adrenalectomized and treated with radioactive orotate and phenobarbital (Table 4 ). It was found that adrenalectomy abolished the increase in specific activity twelve hours after treatment. These data can be considered as evidence that the ATP turnover is linked to the appearance of microsomal RNA.

The subcellula'r distribution of the microsomal RNA after twelve hours of labeling was examined. It can be seen from Table 5 that the largest increase in specific activity occurned in the ribosomal fraction of the microsomes. However, it is interesting that the DOC soluble RNA had a higher specific activity than the ribosomal fraction. The nature of the DOC soluble RNA is not clear; it has been described by different authors as an active participant in a membrane bound protein synthesis unit, the "membron" (Pitot et al. , 1969), as a new type of RNA that is particular to microsomes, and more recently as a contaminating mixture of degraded ribosomes and transfer RNA (Gardner et al., 1968; Hoagland et al., 1968). Moule ( 1968 ) has described a type of RNA that is associated with the DOC soluble fraction of liver that appears to be bound to a lipoprotein complex, and can be recovered from the supernatants after prolonged centrifugation. Although phenobarbital increased the specific activity of the RNA soluble in $0.5 \%$ DOC by $28 \%$, this finding was not pursued, especially since the nature of this RNA and its role in microsomes is not defined.

The fact that phenobarbital had an effect on the specific activity of the ribosomal fraction of hepatic microsomes led to 
experiments designed to determine whether phenobarbital treatment had any effect on the distribution of radioactivity in different types of ribosomes. In rat liver and other tissues, polysomes can be itolated without disrupting the membranes of the ER with detergents (Bloemendel et al., 1964; Loeb et al., 1967). Presumably these polyribosomes are not bound to the ER or are bound by forces weaker than the centrifugal forces used to isolate them. These polysomes are referred to as free polysomes in contrast to those bound to the ER (bound polysomes). As will be discussed below, these two classes of ribosomes seem to have different properties with respect to protein synthesis so it was of some interest to determine whether phenobarbital had any influence on the appearance of RNA in either of these classes of ribosomes. It was found that phenobarbital caused the appearance of a higher specific activity RNA ( $150 \%$ of control) in the bound polysomes twelve hours after treatment with phenobarbital and radioactive orotic acid ( Table 6). The population of free polysomes was more radioactive than control, but was not increased to the same extent as the bound polysomes (free polysomes had $118 \%$ higher specific activity than control). Similar data have been reported by Staubli et al. (1968). In these investigations, electron micrographic techniques were used to measure the alterations in the ER produced by phenobarbital. It was found that a single dose of phenobarbital had increased the RER surface area at sixteen hours after drug treatment. Kato et al. (1966) have also observed that microsomes isolated from rats treated twice with phenobarbital sediment more rapidly in a sucrose gradient than microsomes isolated from control rats. These investigators have interpreted these data to mean that the ER of phenobarbital treated rats has more associated ribosomes.

The fact that phenobarbital causes increased distribution of RNA into bound polyribosomes (as opposed to free polysomes) may 
have particular significance since there is evidence that these two populations have different roles in protein synthesis. Redman (1969) has shown that in liver, ferritin is preferentially synthesized on free polysomes and that serum albumin is preferentially synthesized on bound polysomes. It has also been demonstrated that in vitro, bound polyribosomes from rat brain incorporate leucine to a greater extent than free polysomes, that both types incorporate a rginine to approximately the same extent and that free polysomes incorporate phenylalanine better than bound polyribosomes (Sellinger et al., 1969). It has also been shown that hepatic bound polysomes are responsible for almost all hepatic glycoprotein synthesis (Lawford et al., 1966; Hallinan et al., 1969). These results indicate that the disposition of ribosomal RNA on the membranes of the ER lends some specificity to the types of protein made on these ribosomes.

It is feasible that a drug like phenobarbital, which has such dramatic effects on the ER, would cause synthesis of membrane proteins on membrane bound ribosomes. The re is some indirect evidence that this is the case. Orrenius et al. (1969) found that the first increases in enzyme activity after phenobarbital treatment are in the RER; the se activities are later elevated in the SER. Kato et al. (1966) found that microsomes isolated from phenobarbital treated rats incorporate a variety of amino acids in vitro at a higher rate than microsomes from their controls. When the ribosomes were freed from the membrane by treatment with DOC, both phenobarbital and control ribosomes were equally active. In contrast it was found by Campbell et al. (1968) that phenobarbital treatment caused an equal in vitro amino acid incorporation rate in total microsomes (chich he considered to be both free and bound polysomes) and isolated RER. From these results, it was concluded that free and bound polysomes contributed equally in the 
response to phenobarbital. In a similar experiment during the course of the present investigation, the relative rates of leucine incorporation into nascent peptides in vivo was examined in total ribosomes, bound ribosomes and free ribosomes. It was found that although the specific activity of the total ribosomes (cpm in protein/mg RNA) was approximately equal to the specific activity of the bound ribosomes (as Campbell et al., 1968 had observed), the specific activity of the free polysomes was considerably lower in both control and phenobarbital treated rats ( Table 7 ). These results may indicate that the activity of the total microsomal pellet is a more accurate reflection of the activity of the bound ribosomes than a mixture of free and bound.

The data in Table 7 also indicate that the amino acid incorporating activity of total, bound and free ribosomes was increased to about the same extent by phenobarbital treatment (i. e., approximately $120 \%$ of each respective control.).

The data reported in the present investigation and the cited literature imply that treatment with phenobarbital may have several related effects on protein synthesis within the first twenty four hours after treatment. These effects include:

1. Phenobarbital increases the distribution of RNA to membrane bound ribosomes. Since the relationship of ribosomes to membranes may lend some specificity to the nature of the proteins synthesized on these membranes, the distribution of RNA to the ER may cause particular proteins to be preferentially synthesized.

2. Phenobarbital also causes a moderate increase $(120 \%)$ in the efficiency of amino acid incorporation in both free and bound ribosomes. However, since ribosomes bound to membranes are more active than free ribosomes in incorporating radioactive amino acids (Kato et al., 1966 and Table 7), the absolute 
amount of amino acid incorporation is greater in the membrane bound ribcsomes after phenobarbital. Furthermore, since the distribution of ribosomal RNA to the membranes of the ER is increased by treatment with phenobarbital, the rate of protein synthesis on the RER may be increased by much more than $20 \%$. In this respect, it is important to note that the turnover of ATP was increased by more than $50 \%$ at roughly the same time (figure 4 ); it is possible that this ATP turnover is a reflection of protein synthesis.

Thus it is evident that treatment with phenobarbital results in an increase in the appearance of RNA in the ER (figure 5 and Table 5) with a particularly high increase in the ribosomes of the RER ( Table 6). This increase in microsomal RNA is correlated well in time with an increase in ATP turnover (figure 4). These events may be related by an increase in the efficiency of amino acid incorporation in the ribosomes of the RER. Although there is no definitive evidence that these changes are related to the proliferation of SER seen after repetitive treatment with phenobarbital, it is probably reasonable to suggest that these events are early steps in the growth and differentiation of the hepatocyte after drug treatment.

If the above described events are, indeed, related to the anabolic response of rat liver to phenobarbital, it becomes of some interest to determine what factors control these events. One possibility is that phenobarbital may exert its anabolic activity through adrenal corticoids. It has been mentioned that it is unlikely that the barbiturate causes the release of corticoids (Table 3 ) at the times investigated or that adrenal corticoids directly affect the turnover of ATP described in this report and elsewhere (Ove et al. 1967). However, it is possible that intraperitoneal injection of 
phenobarbital may cause release of corticoids at times not examined and that these corticoids may result in the above described anabolic response. It is well known that adrenal corticoids have an anabolic effect on rat liver, and that these hormones cause alterations in hepatic RNA metabolism (Fiegelson and Fiegelson, 1965). Evidence, in this report and elsewhere (Orrenius et al., 1968b), indicates that adrenalectomy prevents many responses caused by phenobarbital. Recently Orrenius et al. (1969) have suggested that phenobarbital may elevate the levels of corticoids in the liver cell by being an alternate substrate for the microsomal enzymes that metabolize steroids to inactive molecules. Presumably, the elevated intracellular concentration of biologically active steroids would cause the changes in liver metabolism that are usually ascribed to a more direct action of phenobarbital. Although it is not possible to eliminate the prospect that phenobarbital acts entirely through adrenal steroids, there is circumstantial evidence that argues against this possibility. Kato et al. (1965) have demonstrated that phenobarbital stimulates, almost exclusively, incorporation of amino acids into hepatic microsomes while cortisol stimulates the synthesis of proteins for nuclear, microsomal and soluble fractions almost equally (Fiegelson and Fiegelson, 1965). Furthermore, glucose-6phosphatase is one of the first enzymes elevated by corticoids (Ashmore and Weber, 1959) while this enzyme is unaffected by phenobarbital treatment twenty four hours after administration and decreases in specific activity as the SER proliferates (. Ernster et al. , 1965).

Although there is, evidence that phenobarbital does not exert its anabolic influence on rat liver entirely through adrenal steroids, it is also evident, from this report, that adrenalectomized animals do not in some respects, at least, respond to phenobarbital (Table 2,4). These data suggest that corticoids are required for pheno- 
barbital's hepatic response. It is possible that corticoids maintain certain liver functions necessary for hepatic growth after phenobarbital treatment. One such function may be the capacity of the RER to bind ribosomes. It has been recently demonstrated by Cox et al. (1969) that adrenalectomized mice have less bound ribosomes than intact mice. Administration of cortisol $(2.5 \mathrm{mg} /$ $100 \mathrm{~g}$ ) restores the in vivo capacity of the ER to bind ribosomes. It is possible that phenobarbital acts through such an adrenal sensitive system to increase the distribution of RNA to the RER, and that in adrenalectomized rats this response to the drug and its consequences (increased ATP turnover) are prevented. The role of the adrenal gland may be a "permissive" role that allows whatever direct effect phenobarbital has to proceed to its conclusion.

There are several processes that phenobarbital may alter in order to produce the cytoplasmic effects described in this report. One such process would be the rate of synthesis of nuclear RNA. It has been reported by Zemp (1968) that the rate of RNA synthesis in mouse liver is elevated within a few hours after phenobarbital treatment. Orrenius et al. (1968b) have reported that the DNA dependent RNA polymerase in rats is more active within six hours after phenobarbital. These data suggested that phenobarbital might increase the synthesis of nuclear RNA and that this RNA may be directed to the RER.

RNA in the nucleus is labeled quite rapidly after intravenous administration of radioactive orotic acid (Stewart et al., 1968). Therefore, in order for increased synthesis of nuclear RNA to have influenced the distribution of radioactive RNA to the microsomes after the simultaneous administration of precursor and phenobarbital (figure 5, Tables 5,6), the synthesis rate would have to be 
elevated within one hour. With this in mind, experiments were performed as described in Results to determine whether phenobarbital had an immediate effect on the rate of RNA synthesis that might account for the cytoplasmic distribution of RNA observed twelve hours later. The data presented in figure 6 demonstrate that, although the rate of RNA synthesis had increased by three hours after treatment with phenobarbital, in accord with observations made by Zemp (1968), the synthesis rate had not been elevated by one hour after drug treatment. These observations make it unlikely that the cytoplasmic distribution of radioactive RNA seen in Table 6 was the result of increased labeling of nuclear RNA. However, it must be made clear that de novo synthesis of RNA may play a role in the response of the liver to phenobarbital. The above cited literature and the data in figure 6 provide evidence that RNA synthesis is increased by drug treatment; this increase may be related to the distribution of RNA as part of a coordinated response to phenobarbital or may be the result of increased movement of RNA into the cytoplasm.

It was also possible that the increase in specific activity of microsomal RNA (figure 5) might be due to a decreased rate of the degradation of this RNA. The half life of ribosomal RNA has been estimated at five days by Hirsch et al. (1966). It was possible that if treatment with phenobarbital stopped the degradation of RNA in the microsomes entirely and immediately, and if the half life of total microsomal RNA was shorter than for ribosomes, the specific activity of microsomal RNA could be increased by $20 \%$ (figure 5) between twelve and eighteen hours after treatment. A similar effect of phenobarbital has been observed by others (Jick et al. , 1966; Kuriyama et al. . 1969) on the degradation rate of microsomal TPNH-dependent cytochrome c reductase. Furthermore, the 
increase in specific activity of microsomal RNA at twelve hours followed by its decrease in specific activity at twenty four hours as seen in figure 5, might suggest a decrease in degradation of RNA in the face of increased RNA synthesis.

In order to determine the effect of phenobarbital on the half life of microsomal RNA, experiments similar to those of Jick et al. (1966) were performed (See Results) and radioactivity in RNA per liver was estimated. This method of expressing data prevented complications in interpreting results that occur when one estimates specific activity. As can be seen in figure 7 , phenobarbital did reduce the in vivo degradation rate of microsomal RNA. It was calculated that the half life of microsomal RNA in controls was approximately four days while that for phenobarbital treated rats was approximately five and one half days. It is obvious that it would take several days for the specific activity of the microsomal RNA to increase $20 \%$ above control after phenobarbital treatment if the rate of degradation of microsomal RNA were the only factor influencing specific activity in barbiturate treated rats. Furthermore, as mentioned in the Results Section, although evidence exists that in control rats radioactivity from orotic acid is not readily reincorporated into RNA, it is possible that phenobarbital stimulates such a reincorporation. Therefore, the half life in barbiturate treated rats must be considered a maximum value.

It is apparent from the experiments described in the preceeding paragraphs that phenobarbital increases the specific activity of cytoplasmic RNA (especially RNA associated with the RER). It is equally apparent that this increased specific activity cannot be accounted for by increased synthesis of nuclear RNA or decreased cytoplasmic degradations. The only alternative is that phenobarbital increases the efficiency with which the RNA that is synthesized appears in the 
cytoplasm. A similar type of control of the appearance of cytoplasmic ribosomes has been suggested to explain the six-fold increase in ribosomes in regenerating liver (Chaudhuri and Lieberman, 1968) with only a two-fold increase in RNA synthesis. There are a number of factors that may influence the stability of ribosomal precursor RNA in the nucleus or the appearance of ribosomal subunits in the cytoplasm. Some of these are mentioned below:

1. Vaughan et al. (1967a) have indicated that methylation of ribosomal RNA may be necessary for the nuclear $18 \mathrm{~s}$ and $28 \mathrm{~s}$ ribosomal RNA's to become incorporated into ribosomes.

2. Rizzo and Webb (1969) have maintained, from studies with puromycin and cycloheximide, that the number of monosomes in the cytoplasm has a negative influence on the synthesis of new ribosomes.

3. Vaughan et a1. (1967b) and others (Chaudhuri and Lieberman ( 1968), Soeiro et al. (1968)) have provided evidence that ribosomal proteins may be important in the intranuclear stability of ribosomal precursors and their transport to the cytoplasm.

In the present investigation, only two possible influences on the stability and transport of ribosomes were studied. First, since phenobarbital increased the in vivo appearance of ribosomes in the RER, the possibility that phenobarbital might directly influence binding of ribosomes and consequently, increase their transport.was considered. Secondly, the influence of the protein synthesis inhibitor cycloheximide, on the appearance of ribosomes in the cytoplasm was investigated in order to determine the role ongoing protein synthesis might have in the response to phenobarbital.

Since phenobarbital increases the in vivo binding of RNA to the ER (Table 6), it seemed likely that phenobarbital might exert 
some effect on the membranes of the ER to increase their ability to bind ribosomal RNA. This increased binding might cause more movement of RNA from the nucleus and cause the increase in specific activity of RNA in the RER described in Table 6. Investigations by Ernster and Orrenius (.1965) indirectly supported this possibility. These investigators had observed that phenobarbital was bound to the ER very rapidly after its administration (maximum binding by three hours post injection). It was conceivable that phenobarbital exerted an effect directly on the ER or through the synthesis of some molecule on the ER that favored binding of ribosomes. In order to test this possibility RER was collected from rats twelve hours after treatment with either phenobarbital or saline and the ribosomes were removed as described earlier. Polysomes were collected from similarly treated rats that had also been labeled with radioactive orotic acid for twelve hours. These fractions were combined in vitro as described in Results. The data in Table 8 indicate that when polysomes from phenobarbital treated rats were combined with "stripped" RER membranes from phenobarbital rats they bound to the same extent as a similar preparation from saline treated rats. These reconstitution experiments were tried at two concentrations of polysomes to determine whether either the affinity or the capacity of the membrane for polysomes was altered by phenobarbital treatment. Both experiments indicated that phenobarbital had no effect on the binding of polysomes. In experiments not described in Table 8 , polysomes from saline treated rats were combined with membrane from phenobarbital treated rats and vice versa; these experiments were also negative.

Although the in vitro binding experiments indicate that the membranes of the ER isolated from phenobarbital treated rats do not bind polysomes to a greater extent, it is difficult to extrapolate these 
results to the in vivo situation. Simply because polysomes and membranes will combine in vitro (figures 9, 10, 11), one cannot assume that these conditions duplicate the environment in the cell. It is possible that ribosomes in vivo combine with the membrane as monosomes and that messenger RNA is added after the monosomes are fixed to the membrane. Indirect evidence for this conclusion is the fact that after in vitro incubation of microsomes, amino acid incorporating ability is lost, presumably as the result of destruction of messenger RNA. If polyuridylic acid is added to the system, the amino acid incorporating ability is restored, presumably because synthetic messenger RNA has been added to the ribosomes (Weksler and Gelboin, 1967). Furthermore, it is possible that phenobarbital sensitive factors involved in binding of the polysomes are lost during the relatively harsh treatment of the RER used to remove bound ribosomes. Although the present experiment ( Table 8) does not support the conclusion that phenobarbital has an effect on the membranes of the ER that favors binding of ribosomes, this possibility is not excluded by this experiment.

Since it was not possible to demonstrate in vitro an influence of phenobarbital on the binding of ribosomes to the membranes of the ER, investigations were conducted into the possibility that protein synthesis was important to the influence of phenobarbital on cytoplasmic ribosomes. In order to better describe the rationale for this experiment it is necessary to briefly describe recent evidence that indicates that proteins have an important role in the synthesis of ribosomes. Current theory concerning the synthesis of ribosomal RNA (Vaughan et al., 1967b; Starr and Sells, 1969) suggests that the RNA of the ribosomes originates in the nucleolus. DNA in the nucleolus is used to code a 45 S RNA (Steele, 1968) which is sequentially converted into various precursor forms, 41S, $36 \mathrm{~S}$ and $32 \mathrm{~S}$ species. Methylation of the ribose in these RNA's seems to have a role in the specificity of this process. The net result of these 
conversions is the formation of the ribosomal RNA species, 18S and 28S RNA. Throughout this process, the RNA in the nucleolus

- is sequentially coated with protein (Warner, 1966). There is evidence that even the 45S ribosomal precursor RNA is combined with protein (Yoshikawa-Fukuda, 1967) in a 80S ribonucleoprotein. When the 18S and 28S RNAs are fully coated with proteins, they are released as $40 \mathrm{~S}$ and $65 \mathrm{~S}$ subribosomal particles. Apparently the $40 \mathrm{~S}$ and $65 \mathrm{~S}$ particles are assembled into polysomal structures in the presence of messenger RNA (Henshaw, 1968). Warner (1966) has provided evidence that at least twelve proteins are added sequentially to the $65 \mathrm{~S}$ particle before it is fully matured. The site of synthesis of the proteins is not clear. McCarty et al. (1966) have demonstrated that the nucleus has fully assembled ribosomes that are capable of amino acid incorporation and have properíies similar to cytoplasmic ribosomes. It is not necessary. however, to suppose that the proteins are synthesized in the nucleus. Gallwitz and Mueller (1969a, 1969b) have shown that histones, in synchronized Hela cells, are synthesized in the microsomes during replication of DNA. By analogy, it is possible to imagine that a similar coordination could exist between nuclear RNA and proteins.

It has been demonstrated by several investigators that under normal conditions ribosomes can leave the nucleus and appear in the cytoplasm for at least two hours after protein synthesis is stopped with cycloheximide (Rizzo and Webb, 1969; Warner et al., 1966). Warner et al. (1966) have suggested that since $18 \mathrm{~S}$ and 28S RNA does not appear in the cytoplasm except as $40 \mathrm{~S}$ and $65 \mathrm{~S}$ ribonucleoprotein particles, and since cycloheximide does not, under normal conditions, immediately interferewith the appearance of these particles in the cytoplasm or with their incorporation into polysomes, that there must be quantitites of preformed proteins 
available for the assembly of ribosomal subunits. In other experiments, Chaudhuri and Lieberman (1968) have shown that over a short time course cycloheximide treatment does not interfire with the in vivo appearance of ribosomes in the cytoplasm of rat liver. However, in similar experiments with regenerating liver the same investigators demonstrated that a short pretreatment with cycloheximide ( $50 \mathrm{mg} / \mathrm{kg}$ ) reduced the normally elevated rate of appearance of ribosomes to control levels. These investigators concluded that although preformed proteins were available to ribosomal RNA under normal conditions, the appearance of ribosomes was more dependent on ongoing protein synthesis under conditions of rapid hepatic growth (regenerating liver).

Since phenobarbital causes hepatic growth, it seemed likely that translational processes might influence the appea rance of ribosomes in the ER (Table 6). To test this possibility, rats were treated with $0.5 \mathrm{mg} / \mathrm{kg}$ cycloheximide and then thirty minutes later injected with phenobarbital or saline and radioactive orotic acid. After twelve hours, the livers were removed and the specific activity of the bound and free ribosomes was determined. These data are in Table 9.

Treatment with cycloheximide reduced the specific activity of both free and bound ribosomes in phenobarbital and saline treated rats after twelve hours of labeling. The antibiotic had profound effects on the free ribosomes. Both free ribosomes from saline and phenobarbital treated animals had similar specific activities and were reduced to $20 \%$ of their respective controls (not treated with cycloheximide). The bound ribosomes from cycloheximide treated saline rats were less affected ( $60 \%$ of the specific activity of bound ribosomes from controls). In contrast, the bound ribosomes from phenobarbital-cycloheximide rats were drastically reduced in specific activity from their controls ( $20 \%$ of the value for 
rats treated with phenobarbital but not cycloheximide). Furthermore, cycloheximide reduced the specific activity of the bound ribosomes from barbiturate treated.rats to $50 \%$ of the value for similarly treated saline rats. These experiments can be interpreted as indicating that the process that causes ribosomes to appear in the RER more rapidly after phenobarbital is more sensitive to cycloheximide than the similar process in control rats. The preponderance of available literature indicates that cycloheximide, in much higher doses than were used in the present study, does not affect RNA synthesis (under normal conditions), assembly of polysomes or degradation of polysomes (Chaudhuri and Lieberman, 1968; Ennis, 1966; Rizzo and Webb, 1969; Warner et al., 1966; Wettstein et al., 1964; Baliga et al., 1969). A likely explanation for the effects seen in these experiments is that they are the result of decreased protein synthesis.

Although the experiments reported here do not permit unequivocal interpretation of the data presented, it is possible to present a hypothesis that is compatible with the findings of this study and current literature. As mentioned earlier, there is evidence that proteins required for the completion of ribosomal subunits exist in the cell as preformed proteins (Warner et al. , 1966),i. e., in protein pools. Evidence has been cited that these pools are adequate to complete the assembly of ribosomal subunits for a few hours after the administration of cycloheximide to normal rats. It is evident from the data in Table 9 that these pools can be exhausted. Both free and bound ribosomes from cycloheximide and saline treated rats have lower specific activities than their controls. It is also interesting that the bound ribosomes in these animals were relatively less affected than the free ribosomes. In control animals the specific activity of the bound and free polysomes were roughly 
equal; however, cycloheximide reduced their specific activity to $60 \%$ and $20 \%$ of control respectively. One interpretation for this data is that ribosomes destined for the ER have a separate, larger pool of proteins that is unaccessable to ribosomes destined to become free ribosomes. It is even possible that these proteins may determine the ribosome's cytoplasmic distribution. This interpretation is not inconsistent with the distinct physiological roles proposed for these two types of ribosomes (Redman, 1969). An alternative to this interpretation is that as the supply of protein becomes limiting, ribosomes destined for the ER are preferentially assembled.

The data concerning the effect of cycloheximide in phenobarbital rats can also be interpreted in the context of pools of preformed proteins. In rats treated with phenobarbital alone, the specific activity of bound ribosomes is increased to about $150 \%$ of control. In rats treated with phenobarbital and cycloheximide, the specific activity of bound ribosomes is $50 \%$ of cycloheximide treated controls. First, these data suggest that ribosomes destined for the ER are not preferentially assembled during inhibition of protein synthesis with cycloheximide. Secondly, it is likely that ribosomes destined for the RER after treatment with phenobarbital are more dependent on ongoing protein synthesis than in controls. Possibly, the normal protein pool is not available to these ribosomes. An interpretation consistent with these data is that treatment with phenobarbital causes ribosomes to be more efficiently delivered to the ER by circumventing the normal protein pools, in favor of a method of assembly that is more dependent on ongoing protein synthesis. This hypothesis has been presented in diagramatic form in figure 12 . 


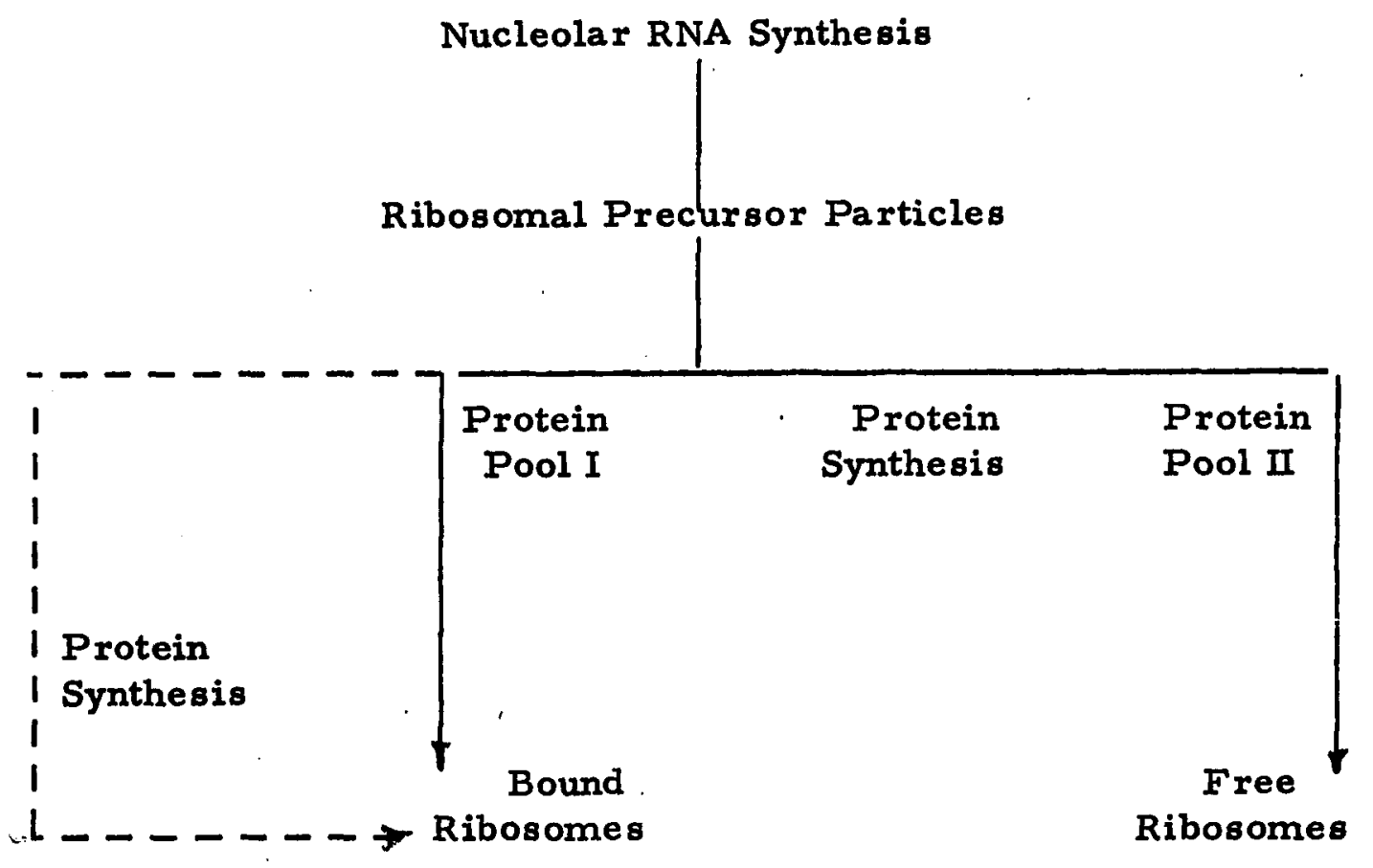

Figure 12

Proposed Relationship of Protein Synthesis to Appearance of Cytoplasmic Ribosomes

Solid lines indicate the pathway used in the assembly of ribosomes in normal rats. Dashed lines indicate the preferred cycloheximide sensitive pathway used after phenobarbital treatment. 
Although, as previously mentioned, the above interpretation of the experiments in this study is not absolute, it has the advantage of explaining data that is otherwise perplexing. For example, although phenobarbital has been shown (figure 4, Tables 5,6 ) to increase the specific activity of microsomal RNA, it has also been shown that this increased specific activity cannot be accounted for by either the synthesis of nuclear RNA (figure 6) or the degráation rate of microsomal RNA (figure 7). It is conceivable that under conditions such as hepatic growth RNA might be more efficiently delivered to the cytoplasm by a route not normally used. In the case of hepatic growth due to phenobarbital, RNA may be directed towards the ER. A similar system has been proposed to explain an increase in the appearance of ribosomes that exceeds the increase in RNA synthesis in regenerating liver (Chaudhuri and Lieberman, 1968).

Earlier in this study, attempts to demonstrate an influence of phenobarbital on the in vitro binding of polysomes to membranes prepared from the RER were described. As the data in Table 8 indicate, phenobarbital, apparently did not alter the binding. In contrast to the in vitro data, it is apparent that ribosomes are preferentially distributed to the ER in vivo after phenobarbital treatment ( Table 6). It is possible to explain this data in the context of more efficient delivery of RNA to the ER. If the membranes of the ER have a fixed capacity to bind ribosomes that is not altered by treatment with phenobarbital, as the data in Table 8 indicate, the rate limiting step may be the rate at which ribosomes are presented to the membrane. In vivo, it may be that phenobarbital, through the cycloheximide sensitive system described above, causes more ribosomes to be presented to the membranes capable of binding them. In vitro, the amount of polysomes is not limiting, and so each membrane would bind to its capacity. Thus the effect of 
phenobarbital on the binding of ribosomes to the ER may not be due to any alteration of either the membranes or the ribosomes per se. Instead, the in vivo binding may be the result of an effect of phenobarbital that relaxes the limitations on the amount of ribosomal RNA available to the membranes.

Alternatively phenobarbital may affect the ribosomes, the membrane or both in a manner that increases in vivo binding and is sensitive to cycloheximide. The increased appearance of RNA in the microsomes may be the result of increased binding (i. e. , membrane bound ribosomes may act as a "sink" which shifts the "equilibrium" between cytoplasm and nucleus so ribosomes enter the cytoplasm). The cycloheximide sensitive protein may be a higher affinity binding site on the ER or some protein associated with such a site. This binding protein would have to be made at the expense of normal sites to explain the data in Table 9. Although this prospect is not supported by the data in Table 8, it cannot be eliminated since loss of material that facilitates binding of RNA from either the polysomes (isolated in $1.25 \%$ DOC) or the "stripped" membranes (washed repeatedly with chelating salts), is a distinct possibility.

In conclusion, some aspects of the early effects of a single dose of phenobarbital on rat liver have been investigated. It was found that simultaneous administration of phenobarbital and radioactive orotic acid resulted in the appearance of an increased specific activity in RNA in the microsomes. The specific activity of the bound ribosomes was particularly increased. The increase in specific activity of microsomal RNA was correlated in time to an increase in ATP turnover. Eviderice is presented that these events are related by an increased protein synthetic capacity of cytoplasmic ribosomes. 
On the assumption that the above described events are related to the proliferation of the SER observed in this report and by others, attempts were made to describe factors that influence the appearance of RNA in the he patic microsomes of phenobarbital treated rats. It was not possible to account for the changes in microsomal RNA by increased nuclear synthesis, decreased microsomal degradation or an increase in the binding affinity of the ER for ribosomes. It was found that cycloheximide dramatically reduced the distribution of ribosomes to the ER, and a hypothesis concerning the delivery of ribosomes to the ER after phenobarbital is advanced. The effects of adrenalectomy on some of these responses to phenobarbital were examined and discussed. 


\section{SUMMARY}

Studies have been conducted into biochemical events that occur in rat liver within the first twenty-four hours after a single dose of $80 \mathrm{mg} / \mathrm{kg}$ of phenobarbital. Some of the observations are as follows.

1. It was found that phenobarbital had no effect on the levels of ATP, ADP or AMP in rat liver within twelve hours after treatment. However, it was found that the drug did increase ATP turnover between fourteen and twenty-four hours after phenobarbital. The increased ATP turnover, like many other effects of phenobarbital, was abolished by adrenalectomy; evidence was presented that the ATP turnover was not due to an adrenal mediated effect of phenobarbital treatment.

2. The effect of phenobarbital on the appearance of mi crosomal RNA was investigated. It was found that phenobarbital modestly increased the appearance of RNA in the microsomes. The increase in microsomal RNA was well correlated in time with the increased ATP turnover described above. Like the ATP turnover, the increased appearance of RNA in microsomes was abolished by adrenalectomy. The submic rosomal distribution of microsomal RNA after treatment with phenobarbital was examined. The major increase in microsomal RNA was in the membrane bound ribosomes of the RER, although free ribosomes and DOC soluble RNA were also increased to a lesser extent. The ribosomes, after treatment with phenobarbital were also more active in amino acid incorporation. 
3. It was found that although phenobarbital apparently increased the rate of synthesis of nuclear RNA three hours after administration, this effect was not early enough to increase the appearance of RNA in the microsomes described above. Investigations into the effect of phenobarbital on the degradation rate of RNA indicated that phenobarbital increased the half life of microsomal RNA from four days to five and one half days. This effect on the rate of degradation of microsomal RNA is not, by itself sufficient to explain the increase in microsomal RNA within twenty four hours.

4. The influence that treatment with phenobarbital might have on the reconstitution of polysomes and ribosome free membranes isolated from the RER was examined. Evidence is presented that drug treatment does not affect this binding; however, it is possible that the conditions of the experiments did not reflect all the in vivo influences on the attachment of ribosomes to the ER.

5. The effects of the protein synthesis inhibitor, cyclohexinride, on the phenobarbital directed increase in bound ribosomes was examined. Cycloheximide retarded the appearance of bound and free ribosomes in both phenobarbital and saline treated rats; however, the effect of cycloheximide was more severe on the appearance of bound ribosomes of phenobarbital treated rats than in their controls.

It is concluded from these investigations that phenobarbital may mediate its anabolic effect on rat liver by increasing the appearance and activity of membrane bound ribosomes. This interpretation is consistant with the effects of phenobarbital on the ER. It is also concluded that this effect of phenobarbital is not directly caused by adrena]. steroids but may be dependent on proper adrenal 
function. Furthermore, the appearance of bound ribosomes in the RER is quite sensitive to alterations in protein synthesis. A hypothesis to provide a unifying explanation for these data is presented. 


\section{BIBLIOGRAPHY}

Ashmore, J. and Weber, G.: The Role of Hepatic Glucose-6Phosphatase in the Regulation of Carbohydrase Metabolism. Vitamins and Hormones 17: 92-132, 1959.

Baliga, B. S., Pronczuk, A. W. and Munro, H.: Mechanism of Cyclohexamide inhibition of Protein Synthesis in a Cell-Free System Prepared from Rat Liver. J. Biol. Chem. 244: $4480-4489,1969$.

Bloemendal, H. , Bont; W.S. and Benedetti, E. I.: Preparation of Rat Liver Polysomes Without the Utilization of Detergent. Biochem. Biophys. Acta 87: 177-180, 1964.

Bloemendal, H. , Bont, W. S., deVries, M. and Benedetti, E. L. : Isolation and Properties of Polysomes and Fragments of the Endoplasmic Reticulum from Rat Liver. Biochem. J. 103: $177-182,1967$.

Bray, G. A.: A Simple Efficient Liquid Scintillator for Counting Aqueous Solutions in a Liquid Scintillation Counter. Anal. Biochem. 1: 279-285, 1960 .

Bucher, N. L. R. and Swaffield, M. N. : Nucleotide Pools and $6-{ }^{14} \mathrm{C}$ orotic Acid Incorporation in Early Regenerating Rat Liver. Biochim. Biophys. Acta 129: 445-459, 1966.

Burton, K.: The Relation Between the Synthesis of Deoxy ribonucleic Acid and the Synthesis of Protein in the Multiplication of Bacteriophage T2. Biochem. J. 61: 473-481, 1955.

Campbell, P. N. and Lawford, G. R.: The Protein Synthesizing Activity of the Endoplasmic Reticulum in Liver, In Structure and Function of the Endoplasmic Reticulum in Animal Cells. Campbell, P. N. and Gran, F. C., pp 57-79 Academic Pres8, London and New York (1968). 
Chaudhuri, S. and Lieberman, I. : Control of Ribosome Synthesis in Normal and Regenerating Liver. J. Biol. Chem. 243: 29-33, 1968.

Claude, A.: Microsomes, Endoplasmic Reticulum and Interactions of Cytoplasmic Membranes, In Microsomes and Drug Oxidations, Gillette, J. R., Conney, A. H. , Cosmides, G. J., Estabrook, R. W., Fouts, J. R. and Mannering, G. J., pp 3-39, Academic Press, New York and London (1969).

Conney, A.H.: Pharmacological Implications of Microsomal Enzyme Induction. Pha rmacol. Rev. 19: 317-366, 1967.

Coon, M. J. and Lu, A.Y.H.: Fatty Acid w-oxidation in a Soluble Microsomal Enzyme System Containing P-450, In Microsomes and Drug Oxidations, Gillette, J. R., Conney, A. H. , Cosmides, G. J., Estabrook, R. W., Fouts, J. R. and Mannering, G.J., pp 151-155, Academic Press, New York and London (1969).

Cox, R. F. and Mathias, A.P.: Cytoplasmic Effects of Cortisol on Liver. Biochem. J. 115: 777-787, 1969.

Dallner, G., Siekevitz, P. and Palade, G. E.: Biogenesis of Endoplasmic Reticulum Membranes I., J. Cell. Biol. 30: 73-96, 1966a.

Dallner, G., Siekevitz, P. and Palade, G. E.: Biogenesis of Endoplasmic Reticulum Membranes II., J. Cell Biol. 30: $97-117,1966 b$.

Dingman, W. and Sporn, M. B.: The Isolation and Physical Characterization of Nuclear and Microsomal Ribonucleic Acid from Rat Brains and Liver. Biochem. Biophys. Acta 61: $164-177,1962$.

Ennis, H. L. : Synthesis of Ribonucleic Acid in L cells During Inhibition of Protein Synthesis by Cycloheximide. Mol. Pharmacol. 2: 543-557, 1966.

Ernster, L. and Orrenius, S.: Substrate Induced Synthesis of the Hydroxylating Enzyme System of Liver Microsomes. Fed. Proc. 24: 1190-1199, 1965.

Fiegelson, P. and Fiegelson, M: Studies on the Mechanism of Corticosterone Action, In Actions of Hormones on Molecular 
Processes, ed. Litwack, G. and Kritchevsky, D. , pp 218 233, John Wiley, New York, London, Sydney (1965).

Fiske, C. and Subbarow, Y.: Phosphocreatine. J. Biol. Chem. 81: 629-679, 1929.

Gallwitz, D. and Mueller, C. : Histone Synthesis In Vitro by Cytoplasmic Microsomes from Hella Cells. Science 163: $1351-1353$, 1969a.

Gallwitz, D. and Mueller, C.: Histone Synthesis In Vitro on Hella Cell Microsomes. J. Biol. Chem. 244: $5947 \overline{-5952}, 1969 \mathrm{~b}$.

Gardner, J.A.A. and Hoagland, M. B.: A Unique Ribonucleic Acid of Low Molecular Weight from Rat Liver Microsomes. J. Biol. Chem. 243: 10-19, 1968.

Gillette, J.R.: Metabolism of Drugs and Other Foreign Compounds by Enzymatic Mechanisms. Prog, in Drug Res. 6: 11-73, 1963.

Gornall, A., Bardawill, C. and David, M.: Determination of Serum Proteins by Means of the Biuret Reaction. J. Biol. Chem. 177: 751-766, 1949.

Hallinan, T., Murphy, C. N. and Grant, J. H. : Early Labeling with Glucosamine of Granular and Agranular Endoplasmic Reticulum and Free Ribosomes from Rat Liver. Arch. Biochem. Biophys. I25: 715-720, 1968.

Henshaw, E. C.: Messenger RNA in Rat Liver Polysomes: Evidence that it Exists as Ribonucleoprotein Particles. J. Mol. Biol. 36: 401-411, 1968.

Hiatt, H. H. : A Rapidly Labeled RNA in Rat Liver. J. Mol. Biol. 5: $217-229,1962$.

Hirsch, C. A. and Hiatt, H. H.: Turnover of Liver Ribosomes in Fed and in Fasted Rats. J. Biol. Chem. 241: 5936-5940, 1966. 
Hoagland, M. B., Wilson, S. H. and Quincey, R. V.: Some Light upon the Membrane RNA Problem, In Regulatory Mechanisms for Protein Synthesis in Mammalian Cells, ed. San Petro, Lamborg, M. R., pp 179-181, Academic Press (1968).

Holzman, J. and Gillette, J.R.: The Effect of Phenobarbital on the Turnover of Microsomal Phospholipid in Male and Female Rats. J. Biol. Chem. 243, 3020-3028, 1968.

Jick, H. and Shuster, L.: The Turnover of Microsomal Reduced Nicotinamide Adenine Dinucleotide Phosphate-Cytochrome $C$ Reductase in the Livers of Mice Treated with Phenobarbital. J. Biol. Chem. 241: 5366-5369, 1966.

Kamin, H., Masters, B.S.S., Gibson, Q. H. and Williams, C. H. : Microsomal TPNH-cytochrome C Reductase. Fed. Proc. 24: $1164-1171,1965$.

Kato, R., Chiesara, E. and Vassanelli, P.: Factors Influencing Induction of Hepatic Microsomal Drug-Metabolizing Enzymes. Biochem. Pharmacol. 11: 211-220, 1962.

Kato, R., Loeb, L. and Gelboin, H. V.: Microsome-Specific Stimulation by Phenobarbital of Amino Acid Incorporation In Vivo. Biochem. Pharmacol. 14: 1164-1166, 1965.

Kato, R., Jondorf, W. R., Loeb, L. A., Ben, T. and Gelboin, H. V.: Studies on the Mechanism of Drug Induced Microsomal Enzyme Activities. Med. Pharmacol. 2: 171-186, 1966.

Kornberg, A.: Reversible Enzymatic Synthesis of Diphosphopyridine Nucleotide and Inorganic Phosphate. J. Biol. Chem. 182: 779-793, 1950.

Kornberg, A. and Pricer, W.E.: Enzymatic Phosphorylation of Adenosine and 2,6 Di-aminopurine Riboside. J. Biol. Chem. 193: $481-495,1951$.

Kuriyama, Y., Omura, T., Siekevitz, P. and Palade, G. E.: Effects of Phenobarbital on the Synthesis and Degradation of Protein Components of Rat Liver Microsomal Membranes. J. Biol. Chem. 244: 2017-2026, 1969.

Lawford, G. R. and Shachter, H.: Biosynthesis of Glycoprotein by Liver. J. Biol. Chem. 241: 5408-5418, 1966. 
Littlefield, J. N. and Keller, E. B.: The Incorporation of $\mathrm{C}^{14}$ Amino Acids into Ribonucleoprotein Particles from the Ehrlich Mouse Ascites Tumor. J. Biol. Chem. 224: 13-30, 1957.

Loeb, J. N., Howell, R. R. and Tompkins, G. M. : Free and Membrane Bound Ribosomes in Rat Liver. J. Biol. Chem. 242: 2069-2074, 1967.

Lowry, O. H., Rosebrough, N. J., Farr, A. L. and Randall, R. J.: Protein Measurement with the Folin Phenol Reagent. J. Biol. Chem. 193: 265-275, 1951.

Lowry, O. H., Passonneau, J. V., Hasselberger, F.X. and Schulz, D.W.: Effect of Ischemia on Known Substrates and Cofactors of the Giycolytic Pathway in Brain. J. Biol. Chem. 239: 18-30, 1964.

Lu, A. Y. H., Junk, K. W. and Coon, M. J.: Resolution of Cytochrome P-450 Containing $w$-hydroxylation System of Liver Microsomes into Three Components. J. Biol. Chem. 244: 3714-3721, 1969.

Mason, H. S., Oxidases. Ann. Rev. Biochem. 34: 595-634, 1965.

McCarty, K. S., Parsons, J. T., Carter, W. A. and Laszlo, J. : Protein-synthetic Capacities of Liver Nuclear Subfractions. J. Biol. Chem. 241: 5489-5499, 1966.

Moncloa, F., Peron, E. G and Dorfman, D.; Fluorometric Determination of Corticosterone in Rat Adrenal Tissue and Plasma: Effect of administering ACTH subcutaneously. . Endocrinology 65: $717-724,1959$.

Moule, Y.: Biochemical Characterization of the Components of the Endoplasmic Reticulum in Rat Liver Cell, In Structure and Function of the Endoplasmic Reticulum in Animal Cells, ed. Campbell, P.N. and Gran, F.C., pp 1-12, Academic Press, London and New York, 1968.

Nash, T.: The Colorimetric Estimation of Formaldehyde by Means of the Hantzch Reaction. Biochem. J. 55: 416-423, 1953.

Okazaki, K., Shull, K. H. and Farber, E.: Effects of Ethionine on Adenosine Triphosphate Levels and Ionic Composition of Liver Cell Nuclei. J. Biol. Chem. 243: 4661-4666, 1968. 
Omura, T., Kuriyama, T., Siekevitz, P. and Palade, G. E. : Effect of Phenobarbital on the Turnover of Microsomal Enzymes, In Microsomes and Drug Oxidations, ed. Gillette, J. R., Conney, A. H., Cosmides, G. J. et al. pp 475-493 Academic Pres8, New York and London, 1969.

Omura, T., Sato, R., Cooper, D. Y., Rosenthal, O. and Estabrook, R. W.: Function of Cytochrome P-450 of Microsomes. Fed. Proc. 24: 1181-1189, 1965.

Orrecius, S., Erricson and Ernster, L.: Phenobarbital Induced Synthesis of the Microsomal Drug Metabolizing System and its Relation to the Proliferation of Endoplasmic Membranes: A Morphological and Biochemical Study. J. Cell. Biol. 25: $627-640,1965$.

Orrenius, S.: Liver Enzyme-Membrane Responses in Drug Induction, In The Interaction of Drugs and Subcellular Components in Animal Cells, ed. P. N. Campbell, pp 97-117 Little Brown and Company, Boston, (1968a).

Orrenius, S., Gnosspelius, Y., Das, M. L. and Ernster, L. : The Hydroxylating Enzyme System of Liver Endoplasmic Reticulum, In Structure and Function of the Endoplasmic Reticulum in Animal Cells, ed. Campbell, P. N. and Gran, F.C., pp 81-96, Academic Press, London and New York, $(1968 \mathrm{~b})$.

Orrenius, S., Das, M. and Gnosspelius, Y.: Overall Biochemical Effects of Drug Induction on Liver Microsomes, In Microsomes and Drug Oxidations, ed. Gillette, J.R., Conney, A. H., Cosmides, G. J. et al., pp 251-277, Academic Press, New York and London (1969).

Ove, P., Takai, S., Umeda, T. and Lieberman, I. : Adenosine triphosphate in Liver after Partial Hepatectomy. J. Biol. Chem. 242: 4963-4971, 1967.

Parsons, J. T. and McCarty, K. S. : Rapidly Labeled Messenger Ribonucleic Acid-Protein Complex of Rat Liver Nuclei. J. Biol. Chem. 243: 5377-5384, 1968. 
Pitot, H. C. and Jost, J.: Studies on the Regulation of the Rate of Synthesis and Degradation of Serine Dehydratase by Amino Acids and Glucose In Vivo, In Regulatory Mechanisms for Protein Synthesis in Mammalian Cells, ed. San Pietro, A., Lamborg, M. R. and Kenny, F. T., pp 283-298, Academic Pres8, New York (1968).

Pitot, H. C., Sladek, N. , Ragland, W., Murray, R. K., Moyer, G. Soling, H. D. and Jost, J.: A Possible Role of the Endoplasmic Reticulum in the Regulation of Genetic Expression, the Membron Concept, In Microsomes and Drug Oxidations, ed. Gillette, J.R., Conney, A.H., Cosmides, G. J. et al. pp 59-79, Academic Press, New York and London (1969).

Preiss, B. and Block, K.: w (omega)-oxidation of Long Chain Fatty Acids in Rat Liver. J. Biol. Chem. 239: 85-93, 1964.

Redman, C. M. : Biosynthesis of Serum Proteins and Ferritin by Free and Attached Ribosomes of the Rat Liver. J. Biol. Chem. 244: 4308-4315, 1969.

Rizzo, A. J. and Webb, T.E.: Ribosome Formation in Rat Liver: Evidence for Post-transcriptional Control. Biochim. Biophys. Acta 195: 109-122, 1969.

Schenkman, J. B., Remmer, H. and Estabrook, R. W. : Spectral Studies of Drug Interaction with Hepatic Microsomal Cytochrome. Mol. Pharmacol. 3: 113-123, 1967.

Schmidt, G. and Thannhauser, S. J. : A Method for the Determination of Deoxyribonucleic Acid, Ribonucleic Acid and Phosphoproteins in Animal Tissues. J. Biol. Chem. 161: 83, 1945.

Sellinger, O.Z. and Ohlsson, W.G.: Protein Synthesis on Free and Endoplasmic Reticulum Bound Polysomes of Rat Brain. Life Sci. 8: 1083-1088, 1969.

Shuster, L. and Jick, H.: The Turnover of Microsomal Protein in the Livers of Phenobarbital Treated Rats. J. Biol. Chem. 241: $5361-5365,1966$.

Siekevitz, P.: Origin and Functional Nature of Microsomes. Fed. Proc. 24: 1153-1155, 1965. 
Soeiro, R., Vaughan, M. H. and Darnell, J.E.: The Effect of Puromycin on Intranuclear Steps in Ribosome Biosynthesis. J. Cell. Biol. 36: 91-103, 1968.

Star1, J. L. and Sells, B. H. : Methylated Ribonucleic Acids. Physiol. Rev. 49: 623-669, 1969.

Staubli, W., Hes8, R. and Weibel, E. R.: Correlated Morphometric and Biochemical Studies on the Liver Cell II. J. Cell Biol, 42: $92-122,1969$.

Steele, W. J.: Localization of Deoxyribonucleic Acid Complementary to Ribosomal Rilıonucleic Acid and Preribosomal RiboNucleic Acid in the Nucleous of Rat Liver. J. Biol. Chem. 243: $333-3341,1968$.

Stewart, G. A. and Farber, E. : The Rapid Acceleration of Hepatic Nuclear Ribonucleic Acid Breakdown by Actinomycin but not by Ethionine. J. Biol. Chem. 243: 4479-4485, 1968.

Strittmatter, P.: Protein and Coenzyme Interactions in the NADHCytochrome $b_{5}$ Reductase System. Fed. Proc. 24: 11.56-1163, 1965.

Suss, R., Bloebel, G. and Pitot, H. C.: Rat Liver and Hepatoma Polysome-Membrane Interaction In Vitro. Biochem. Biophys. Res. Comm. 23: 299-304, 1966.

Tata, J.R.: The Formation and Distribution of Ribosomes During Hormone-Induced Growth and Development. Biochem. J. 104: $1-16,1967$.

Truman, D. E.S. and Korner, A.: Incorporation of Amino Acids into the Protein Isolated from Mitochondria. Biochem. J. 83: $588-596,1962$.

Vaughan, M. H. , Soeiro, R., Warner, J. R., and Darnell, J. E.: The Effect of Methione Deprivation: on Ribosome Synthesis in HeLa Cells. Proc. Natl. Acad. Sci. U.S. 58: 1527-1542, $1967 a$.

Vaughan, M. H., Warner, J.R. and Darnell, J.E.: Ribosomal Precursor Particles in the HeLa Cell Nucleus, J. Mol. Biol. 25: 235-251, $1967 \mathrm{~b}$. 
Villa-Trevino, S., Shull, K. H. and Farber, E.: The Inhibition of Liver Ribonucleic Acid Synthesis by Ethionine. J. Biol. Chem. 241: 4670-4674, 1966.

Warburg, O. and Christian, W.: Isolierung und Kristallisation des ga rungsterments endase. Bioch. Z. 310: 384-421, 1942.

Warner, J.R.: The Assembly of Ribosomes in HeLa Cells. J. Mol. Biol. 19: 383-398, 1966.

Warner, J.R., Girard, M., Latham, J.M. and Darnell, J. E.: Ribosome Function in HeLa Cells in the Absence of Protein Synthe sis. J. Mol. Biol. 19: 373-382, 1966.

Webb, T.E. and Blobel, G.: Polysomes in Rat Tissues I. Canc. Res. 24: 1229-1237, 1964.

Weksler, M. E. and Gelboin, H. V.: Studies on the Removal of Endogenous Messenger Ribonucleic Acid Activity from Rat Liver Microsomes. J. Biol. Chem. 242: 727-735, 1967.

Wettstein, F.O., Noll, H. and Penman, S.: Effect of Cycloheximide on Ribosomal Aggregates Engaged in Protein Synthesis In Vitro. Biochim. Biophys. Acta 87: 525-528, 1964.

Wilson, R.G., Wortham, J.S. and Gelboin, H. V.: The Effect of Methylcholanthrene, Phenobarbital and Aflotoxin on RNA Polymerase of Rat Liver. Adv. Enzyme Regulation 5: 385$395,1967$.

Yeh, S. D. J. and Maurice, S. E. : Quantitative Aspects of Cycloheximide Inhibition of Amino Acid Incorporation. Biochem. Pharmacol. 18: 1919-1926, 1969.

Yoshikawa-Fukuda, M.: The Intermediate State of Ribosome Formation in Cultured Animal Cells. Biochem. Biophys. Acta 145: 651-663, 1967.

Zemp, J.W.: The Effect of Phenobarbital on the Turnover of Nuclear and Microsomal RNA in Mouse Liver. Pharmacologist 10: 179, 1968. 